\title{
Adolescents Selling Sex and sex as Self-Injury
}

Cecilia Fredlund

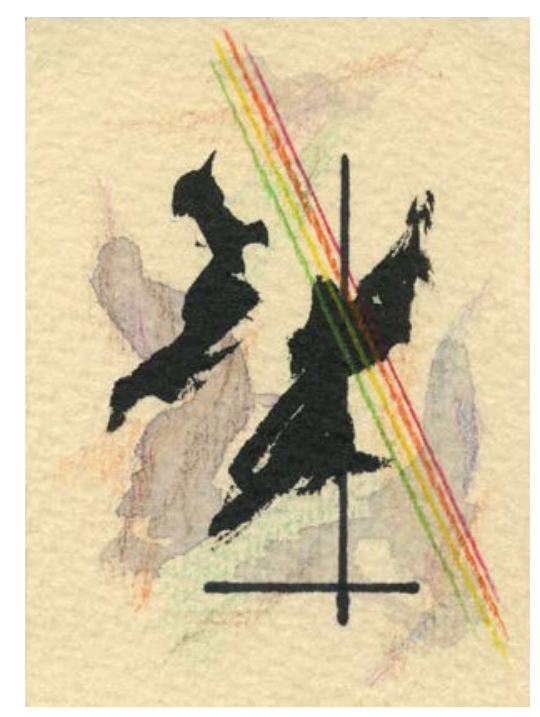




\section{Adolescents Selling Sex and sex as Self-Injury}

Cecilia Fredlund

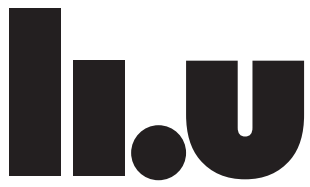

LINKÖPING UNIVERSITY

Department of Clinical and Experimental Medicine

Linköping University, Sweden

Linköping 2019 
Adolescents Selling Sex and Sex as Self-Injury

(C) Cecilia Fredlund, 2019

Cover picture: Lars Fredlund

ISBN: 978-91-7685-204-0

ISSN: 0345-0082

Printed in Sweden by LIU-Tryck, Linköping, Sweden, 2019 
To adolescents who have experienced sexual abuse

"Actually it started a long time ago with [sexual] abuse when I was little, plus physical abuse. It has given me a fear of intimacy that still affects my life. But since I had pressure from those around me and from healthcare I was desperate for self-harm behaviour that was invisible or left no scars. And through the Internet I started to find guys, but it was not enough so I started to sell myself for more abasement. When I got paid I lost all the rights to my body and even the possibility to say no. As a further step in this I agreed to unprotected intercourse if there was a desire for this. I still have suicidal thoughts and anxiety if someone just touches me." Female, 30 years old 



\section{Contents}

ABSTRACT 1

$\begin{array}{ll}\text { LIST OF PUBLICATIONS } & 3\end{array}$

ABBREVATIONS 4

BACKGROUND OF THE THESIS

Introduction $\quad 5$

$\begin{array}{lc}\text { Concepts and terminology } & 6\end{array}$

$\begin{array}{ll}\text { The prevalence of adolescents selling sex } & 8\end{array}$

$\begin{array}{ll}\text { The selling of sex } & 8\end{array}$

Adolescents selling sex and social context 9

$\begin{array}{ll}\text { Selling sex, abuse and harassment } & 10\end{array}$

$\begin{array}{ll}\text { Adolescents selling sex and mental health } & 10\end{array}$

Male prostitution $\quad 11$

$\begin{array}{ll}\text { Motives for selling sex } & 12\end{array}$

$\begin{array}{ll}\text { Self-injurious behavior } & 13\end{array}$

$\begin{array}{ll}\text { Sex as self-injury } & 15\end{array}$

$\begin{array}{ll}\text { The function of self-injury } & 16\end{array}$

$\begin{array}{ll}\text { Neuropathology and self-injury } & 17\end{array}$

$\begin{array}{ll}\text { Trauma and self-injury } & 18\end{array}$

$\begin{array}{ll}\text { To confide } & 20\end{array}$

$\begin{array}{ll}\text { AIM OF THE THESIS } & 21\end{array}$

$\begin{array}{ll}\text { Study I } & 21\end{array}$

$\begin{array}{ll}\text { Study II } & 21\end{array}$

Study III 21

Study IV $\quad 22$ 
MATERIAL AND METHODS

$\begin{array}{ll}\text { Participants } & 23\end{array}$

$\begin{array}{ll}\text { Procedure } & 24\end{array}$

Studies I-III $\quad 24$

Study IV 24

$\begin{array}{ll}\text { Measures } & 26\end{array}$

Studies I-III 26

Study IV 30

Data analysis 31

Ethical considerations $\quad 33$

Funding for the studies $\quad 34$

RESULTS OF THE EMPIRICAL STUDIES

$\begin{array}{ll}\text { Studies I-II - Adolescents selling sex } & 35\end{array}$

$\begin{array}{ll}\text { Studies III-IV - Sex as self-injury } & 37\end{array}$

$\begin{array}{ll}\text { GENERAL DISCUSSION } & 41\end{array}$

Summary and strengths - Adolescents selling sex 41

Summary and strengths - Sex as self-injury $\quad 44$

Methodological considerations and limitations $\quad 46$

$\begin{array}{lr}\text { Clinical implications } & 50\end{array}$

Future directions $\quad 53$

CONCLUSIONS

SAMMANFATTNING PÅ SVENSKA

ACKNOWLEDGEMENTS IN SWEDISH

$\begin{array}{ll}\text { REFERENCES } & 61\end{array}$

APPENDIX: Questionnaire used for Study IV 75 


\section{Abstract}

There are today only a few population-based studies in the world investigating the prevalence of and associated risk-factors with adolescents selling sex and so far no earlier populationbased study has been found investigating adolescents motives for selling sex. Further, to use sex in means of self-injury (SASI) is a behaviour that has been highlighted in Sweden the last years but it is a new field of research and a behaviour in need of conceptualization

The aim of this thesis was to investigate the prevalence of, associated risk factors with, motives for and manifestations of adolescents selling sex and the use of sex as self-injury (SASI). For the thesis, two nationally representative cross-sectional population surveys with third year students at Swedish high schools were collected in $2009(\mathrm{n}=3498$, mean age 18.3 $+/-0.6$ years, response rate $60.4 \%)$ and in $2014(\mathrm{n}=5839$, mean age $18.0+/-0.6$ years, response rate $59.7 \%$ ). Further, the motives and manifestations of SASI were investigated in an anonymous self-selected, open-ended questionnaire published on websites of nongovernmental organizations offering help and support to women and adolescents ( $n=199$, mean age $27.9+/-9.3$ years). Quantitative and qualitative methods were used for data analyses.

In the 2009 population-based survey, $1.5 \%(n=51)$ of the adolescents reported having sold sex on at least one occasion, but in 2014 the prevalence was slightly lower at $0.9 \%(n=51)$. SASI was reported by $3.2 \%$ of girls $(n=100)$ and $0.8 \%$ of boys $(n=20)$. Both selling sex and SASI were associated with various adverse factors such as experience of sexual abuse, emotional and physical abuse, poor mental health and self-injury. Adolescents selling sex had sought help and support for different problems and worries to a greater extent compared to peers. Contact with healthcare for various psychiatric problems such as suicide attempts, depression and eating disorders was common for adolescents using SASI. Further analysis showed that adolescents selling sex are a heterogeneous group in regard to underlying motives for selling sex, which included emotional and material reasons as well as pleasure. Depending on their underlying motives, adolescents selling sex were found to differ in regard 
to compensation received, age of the buyer, means of contact with the buyer, sexual orientation, experience of sexual abuse and the use of SASI. By using data from an openended questionnaire, SASI was described as deliberate or self-inflicted sexual situations that could include psychological and physical harm. SASI was used as a way to regulate negative feelings, such as anxiety, or to get positive or negative confirmation and the behaviour could be hard to stop.

In conclusion, selling sex and SASI occurs among Swedish adolescents and the behaviours are associated with sexual, physical and emotional abuse and poor mental health, including trauma symptoms. In regard of the motives and manifestations of SASI, the behaviour could be compared to direct self-injurious behaviours. Data from this thesis suggest that more attention should be paid in healthcare to recognizing adolescents selling sex and SASI in order to prevent further traumatization and victimization.

Keywords

Adolescents, Selling sex, Sex as self-injury, Child sexual exploitation, Sexual abuse. 


\section{List of Publications}

I. Svensson, F., Fredlund, C., Svedin, C.G., Priebe, G., \& Wadsby, M. (2013).

Adolescents selling sex: Exposure to abuse, mental health, self-harm behavior and the need of help and support - a study of a Swedish national sample. Nordic Journal of Psychiatry, 67, 81-88. Doi:10.3109/08039488.2012.679968

II. Fredlund, C., Dahlström, Ö., Svedin, C.G., Wadsby, M., Jonsson, L.S., \& Priebe, G. (2018). Adolescents' motives for selling sex in a welfare state - a Swedish national study. Child Abuse and Neglect, 81, 286-295.

Doi:10.1016/j.chiabu.2018.04.030

III. Fredlund, C., Svedin, C.G., Priebe, G., Jonsson, L., \& Wadsby, M. (2017). Selfreported frequency of sex as self-injury (SASI) in a national study of Swedish adolescents and association to sociodemographic factors, sexual behaviors, abuse and mental health. Journal of Child and Adolescent Mental Health, 11, 9. Doi:10.1186/s13034-017-0146-7

IV. Fredlund, C., Wadsby, M., \& Jonsson, L.S. Motives and manifestations of sex as self-injury. (In manuscript). 


\section{Abbreviations}

\begin{tabular}{|c|c|}
\hline ADD & Attention deficit disorder \\
\hline ADHD & Attention deficit hyperactivity disorder \\
\hline BPD & Borderline personality disorder \\
\hline DBT & Dialectal behaviour therapy \\
\hline DSH & Deliberate self-harm \\
\hline DSM & The Diagnostic and Statistical Manual of Mental Disorder \\
\hline GHB & Gamma-hydroxybutyric acid \\
\hline HOPP & Riksorganisationen mot sexuella övergrepp \\
\hline HPA & Hypothalamic-pituitary-adrenal \\
\hline ICD & International Classification of Diseases \\
\hline ISSS & International Society of the Study of Self-Injury \\
\hline KMO & Kaiser-Meyer-Olkin measure of sampling adequacy \\
\hline MDPV & Methylenedioxypyrovalerone \\
\hline NGO & Non-governmental organization \\
\hline NSSI & Non-suicidal self-injury \\
\hline NSSID & Non-suicidal self-injury disorder \\
\hline PTS & Post-traumatic stress \\
\hline PTSD & Post-traumatic stress disorder \\
\hline RFSL & Riksförbundet för homosexuellas, bisexuella, transpersoners och queeras rättigheter \\
\hline RFSU & Riksförbundet för sexuell upplysning \\
\hline RISE & Riksföreningen mot incest och andra sexuella övergrepp i barndomen \\
\hline SASI & Sex as self-injury \\
\hline SIB & Self-injurious behaviour \\
\hline SPSS & Statistical Package for the Social Sciences \\
\hline STI & Sexually transmitted infection \\
\hline TSCC & Trauma symptom checklist for children \\
\hline $\mathrm{UN}$ & United Nations \\
\hline vs & Versus \\
\hline WONSA & World of no sexual abuse \\
\hline
\end{tabular}




\section{Background of the Thesis}

\section{Introduction}

About 1 million children are estimated to be exposed to child sexual exploitation in the world today, making it one of the most hidden global forms of violence (Greenbaum, 2018; Rand, 2010). The first world congress against commercial child sexual exploitation was held in Stockholm, Sweden in 1996. In relation to the congress, the Swedish Government announced an action plan in 1998 regarding commercial sexual exploitation of children, stating that child sexual exploitation rarely occurred in Sweden (Davidson \& Runegrund, 1999; Socialdepartimentet, 1998). However, since this statement studies have found that child sexual exploitation does exist in Sweden and the prevalence of adolescents with the experience of selling sex has been estimated at 1-2\% of high school populations (Ahlgren, Näslund, \& Roslander, 2009; Fredlund, Svensson, Svedin, Priebe, \& Wadsby, 2013; Svedin $\&$ Priebe, 2007). This prevalence is in line with population-based studies from other Western countries (McNeal \& Walker, 2016; Mossige, Ainsaar, \& Svedin, 2007; Pedersen \& Hegna, 2003). Contrary to common beliefs, population-based studies indicate that more boys than girls sell sex for compensation (Fredlund et al., 2013; McNeal \& Walker, 2016; Mossige et al., 2007; Pedersen \& Hegna, 2003; Svedin \& Priebe, 2007). These findings lead to the following questions: Why do adolescents sell sex in social welfare countries such as Sweden? Which are the most important factors associated with the behaviour? Except for economic compensation, are there other motives behind the behaviour? Are there any gender differences in the motives for selling sex?

Sex as self-injury (SASI) is a behaviour that has been highlighted in Sweden in the media, in bachelor's theses, and by organizations and professionals working with women and young people (Carlsson, 2012; Engvall, 2008, 2011; Gimstam-Jarl \& Thögersen, 2012; Jenstav \& Meissner, 2016; Jonsson \& Lundström Mattsson, 2012; Karlsson, Lönnbohm, \& Söderberg, 
2013). However, SASI is a behaviour that is yet not conceptualized and is far from accepted in the research field.

\section{Concepts and terminology}

It has been estimated that there are about 2.5 million victims of trafficking in the world, of which $20-50 \%$ are estimated to be children (Miller-Perrin \& Wurtele, 2017). Human trafficking is defined according to the United Nations Protocol to Prevent, Suppress, and Punish Trafficking in Persons, Especially Women and Children (United Nations, 2000) as:

The recruitment, transportation, transfer, harbouring or receipt of persons, by means of the threat or use of force or other forms of coercion, of abduction, of fraud, of deception, of the power or of a position of vulnerability or of the giving or receiving of payments or benefits to achieve the consent of a person having control over another person, for the purpose of exploitation. Exploitation shall include, at a minimum, the exploitation of the prostitution of others or other forms of sexual exploitation, forced labour or services, slavery or practices similar to slavery, servitude of the removal of organs. (Article 3)

The term 'trafficking' implies physical movement and has often been associated with movement over borders. However, child sexual exploitation is currently most commonly carried out domestically by a person of the same nationality (Miller-Perrin \& Wurtele, 2017). The term Commercial sexual exploitation of children was defined by the First World Congress against Commercial Sexual Exploitation of Children (held in Stockholm, Sweden in 1996) as:

Sexual abuse by an adult and remuneration in cash or kind to the child or a third person or persons. The child is treated as a sexual object and as a commercial object. (p. 1)

The commercial element can include all forms of compensation which could be seen in many kinds of child sexual exploitation such as child pornography, child prostitution, child marriage and child sex tourism (Miller-Perrin \& Wurtele, 2017).

In the literature, different terms are used for adolescents having sex for compensation such as child prostitution, juvenile prostitution, survival sex and child sexual exploitation. Studies indicate that young people who sell sex usually do not identify themselves with the term 
'prostitution' since the selling of sex is often seen as something temporary and they are usually not dependent on the economical compensation. The term 'prostitution' is often considered by young people as a long-term or full-time occupation, which they usually do not identify themselves with (Jonsson \& Svedin, 2012; Lavoie, Thibodeau, Gagné, \& Hébert, 2010; van de Walle, Picavet, van Berlo, \& Verhoeff, 2012) since it is common to have sold sex less than five times (Fredlund et al., 2013; Lavoie et al., 2010; Svedin \& Priebe, 2007). On the other hand, the term 'child sexual exploitation' is often associated with the child being exploited by an adult (Hallett, 2017). Studies indicate that adolescents selling sex are not only exploited by adults but also sell sex to peers (Edinburgh, Pape-Blabolil, Harpin, \& Saewyc, 2015; Fredlund et al., 2013; Lavoie et al., 2010), which is why not all adolescents selling sex might identify with this term. Also, victims of commercial sexual exploitation do not always view themselves as victims until later on, when they realize the extent of abuse and violence that they have suffered (Rand, 2010). In regard to this discussion, this thesis uses the term selling sex for compensation, but considers it as a form of child sexual exploitation when the person is under 18 years of age, since buying, but not selling, sexual services is considered a criminal act under Swedish law. In fact, if the person is under 15 years of age it is considered rape (The Swedish Penal Code, Chapter 6, 1962:700).

Since sex as self-injury (SASI) is a new concept in the research field, there is no common definition of the behaviour. In a report from the Children's Welfare Foundation Sweden, a definition of SASI was suggested as:

'When a person has a pattern of seeking sexual situations involving mental or physical harm to themselves. The behavior causes significant distress or impairment in school, work, or other important areas.' (Jonsson \& Lundström Mattsson, 2012)

An alternative definition for SASI was formulated by Stockholms Tjejjour, a Swedish nonprofit organization working to help and support young females (Jenstav \& Meissner, 2016):

"To repetitively and recurrently feel intense feelings such as shame, guilt, anxiety, disgust and self-hatred. And that these feelings are confirmed and/or temporarily alleviated by repetitive and recurrent exposure to sexual and physical abuse, humiliation and violation or by the repetitive and recurrent search for other sexual situations that distress but do not necessarily, but often, involve a third party being responsible for causing the physical and/or mental injury." 


\section{The prevalence of adolescents selling sex}

The first Swedish study investigating the prevalence of adolescents selling sex was conducted in 2004 by Svedin and Priebe and included 4339 participants from the third year of high school in five Swedish cities. It found that $1.4 \%$ of adolescents $(1 \%$ of girls and $1.8 \%$ of boys) had experiences of selling sex for compensation (Svedin \& Priebe, 2004; Svedin \& Priebe, 2007). This study was part of the Baltic Sea Regional Study on Adolescent Sexuality including the countries Norway, Sweden, Lithuania, Estonia and Poland. According to this study, the overall prevalence of adolescents selling sex in the Baltic Sea region was $3.7 \%$ for girls and $9.4 \%$ for boys, and the highest numbers for both boys and girls were seen in Poland (Mossige et al., 2007). Similar numbers to the Swedish study were seen in a large Norwegian study from 2003 with a sample from the public and private school system in Oslo, including almost 11000 adolescents aged $14-17$ years. In total, $1.4 \%$ ( $0.6 \%$ of girls and $2.1 \%$ of boys) reported that they had sold sex for compensation on at least one occasion (Pedersen \& Hegna, 2003). Further, similar numbers have been found in longitudinal studies from the United States, indicating that $1-2 \%$ started to sell sex during adolescence or early adulthood (Kaestle, 2012; McNeal \& Walker, 2016), and in an American nationally representative study of about 13000 adolescents, $3.5 \%$ were found to have exchanged sex for money or drugs on at least one occasion (Edwards, Iritani, \& Hallfors, 2006). However, the prevalence of adolescents selling sex might be underestimated in studies based on school samples, since selling sex is associated with feeling unhappy at school and dropping out of school is more commonly seen among adolescents selling sex (Brawn \& Roe-Sepowitz, 2008; Kaestle, 2012; McNeal \& Walker, 2016).

\section{The selling of sex}

Studies concerning adult prostitution indicate that the selling of sex often starts during adolescence (Bagley \& Young, 1987; Farley, 2003; Kotrla, 2010). For adolescents, the most common compensation is money, but other kinds of compensation such as drugs, alcohol and cigarettes, food and shelter, matrial things and friendship are also seen (Abelsson \& Hulusjö, 2008; Fredlund et al., 2013; Svedin \& Priebe, 2007; van de Walle et al., 2012). The most common sexual activities for which compensation is given in Sweden are vaginal intercourse, oral sex, masturbation in front of another person, display of genitals, and being photographed naked or in sexual situations (Abelsson \& Hulusjö, 2008; Fredlund et al., 2013; Svedin \& 
Priebe, 2007). According to an interview study of young women selling sex, physically violent sex was recurrently carried out in return for compensation (Jonsson \& Svedin, 2012).

The Internet is a common mean of contact for selling sex among adolescents (Edinburgh et al., 2015; Fredlund et al., 2013; Jonsson, Svedin, \& Hyden, 2014). However, in older population-based studies, adolescents often came into contact with the buyer through social networks or on their own (Lavoie et al., 2010; Svedin \& Priebe, 2007). Hence, the selling of sex among adolescents could often be seen as an independent act where no pimp or adult is involved (Edinburgh et al., 2015; Fredlund et al., 2013; Jonsson et al., 2014). The buyers has been described as both male and female (Fredlund et al., 2013; Lavoie et al., 2010; Moynihan et al., 2018) and in a Swedish interview study, the buyers were described as mostly men but a heterogeneous group in regard to age, occupation and civil status (Jonsson \& Svedin, 2012).

\section{Adolescents selling sex and social context}

In population-based studies, there has been an inconsistency in regard to associations between adolescents selling sex and sociodemographic factors such as parents' education, the family's economic situation and immigrant background (Fredlund et al., 2013; Lee, Shek, \& Busiol, 2016; Pedersen \& Hegna, 2003; Svedin \& Priebe, 2007). However, several studies have found an association between adolescents selling sex and not living with two parents (Fredlund et al., 2013; Kaestle, 2012; McNeal \& Walker, 2016; Pedersen \& Hegna, 2003; Svedin \& Priebe, 2007), having unemployed parents (Svedin \& Priebe, 2004, 2009) and a poor parent-child relationship (Fredlund et al., 2013; McNeal \& Walker, 2016; Svedin \& Priebe, 2007). Running away from home could be seen as a risk factor for selling sex among adolescents (Edinburgh et al., 2015; Edwards et al., 2006; Hwang \& Bedford, 2003; Kaestle, 2012; Roe-Sepowitz, 2012; Song \& Morash, 2016). Further, survival sex (giving sex in exchange for food and housing) has been seen among $28 \%$ of adolescents living on the street in an study of homeless adolescents (Greene, Ennett, \& Ringwalt, 1999). In Sweden, there have been several reports from the police in recent years concerning sexual exploitation among young immigrants arriving alone in Sweden (Länsstyrelsen, 2015; Polisen, 2014, 2016, 2017). 
Selling sex, abuse and harassment

Sexual abuse is a recurrent risk factor for selling sex among adolescents (Bagley \& Young, 1987; Hershberger et al., 2018; Kaestle, 2012; Lavoie et al., 2010; Svedin \& Priebe, 2007), and sexual abuse has been found in interviews to be an important reason contributing to the start of prostitution (Bagley \& Young, 1987; Dunlap, Golub, \& Johnson, 2004; Jonsson \& Svedin, 2012). According to the Swedish population-based study from 2004, $61 \%$ of the girls and $29.7 \%$ of the boys selling sex had been exposed to penetrative sexual abuse and the sexual abuse had often preceded the selling of sex (Svedin \& Priebe, 2007). Exposure to child sexual abuse and neglect more than doubles the risk of prostitution in young adulthood (Wilson \& Widom, 2010). The experience of physical and emotional violence is also associated with selling sex among young people (Bagley \& Young, 1987; Farley, 2003; Kaestle, 2012; Pedersen \& Hegna, 2003; Roe-Sepowitz, 2012; Song \& Morash, 2016).

Violence and threats are often reported in relation to the selling of sex among adolescents (Edinburgh et al., 2015; Farley, 2003; Heilemann \& Santhiveeran, 2011; Jonsson \& Svedin, 2012). According to a content analysis from 31 empirical studies, 50-93\% of female adolescents in prostitution had been physically harmed by customers, pimps, brothel owners, law enforcement officers, other prostitutes or passers-by (Heilemann \& Santhiveeran, 2011). In an American study of adolescents arrested for prostitution, about $50 \%$ had been exposed to rape or assault by a sex buyer, while violence from pimps was not as common (Edinburgh et al., 2015). In a Swedish interview study of girls 15-25 years selling sex, experiences of violence, threats, rape and being filmed or photographed against their will were common. Some were even afraid of being killed during sexual encounters (Jonsson \& Svedin, 2012; Jonsson, Svedin, \& Hydén, 2015).

\section{Adolescents selling sex and mental health}

Selling sex among adolescents has been associated with poor self-esteem (Bagley \& Young, 1987; Svedin \& Priebe, 2009; Svedin, Priebe, Wadsby, Jonsson, \& Fredlund, 2015) and poor mental health like depression and anxiety (Bagley \& Young, 1987; Barnert et al., 2017; Svedin \& Priebe, 2007). Female adolescents selling sex have been found to suffer from depression symptoms, PTSD, suicidal thoughts, feelings of shame and guilt and self-injury. 
Further, dissociation, alcohol and drug abuse were seen as coping strategies for a life in prostitution (Heilemann \& Santhiveeran, 2011). Several other studies have found high levels of trauma symptoms among adolescents selling sex (Barnert et al., 2017; Farley, 2003; Hershberger et al., 2018), suicide attempts and self-injury (Bagley \& Young, 1987; Barnert et al., 2017; Edinburgh et al., 2015), behavioural problems, higher levels of alcohol-related problems and higher drug use involvement have been noted (Barnert et al., 2017; Edwards et al., 2006; Hershberger et al., 2018; Kaestle, 2012; McNeal \& Walker, 2016; Pedersen \& Hegna, 2003; Tikkanen, Abelsson, \& Forsberg, 2011). According to the Norwegian study, as many as $32.8 \%$ of the boys and $11.6 \%$ of the girls selling sex had used heroin (Pedersen \& Hegna, 2003).

\section{Male prostitution}

Population-based studies of adolescents selling sex in the Nordic countries, the Baltic Sea region and the United States indicate that more boys than girls sell sex for compensation (Kaestle, 2012; McNeal \& Walker, 2016; Mossige et al., 2007; Pedersen \& Hegna, 2003; Svedin \& Priebe, 2007). According to an international review report including 17 studies involving sexually exploited boys, the prevalence of boys selling sex is $1.7-4.8 \%$, but in street-based samples of boys from e.g. Brazil, Pakistan and Ghana, the numbers are as high as $16-45 \%$. Six studies were found reporting both males and females to be sexual exploiters of boys (Moynihan et al., 2018). In a Canadian clinical study of bisexual and homosexual men, $10 \%$ had been selling sex before the age of 18 years and the selling of sex was associated with current depression (Ratner et al., 2003).

According to the review, sexually exploited boys had more experience of child abuse, substance use (drugs and alcohol), conduct problems and mental health problems such as anxiety, depression and self-injury compared to their peers (Moynihan et al., 2018). In a Norwegian study, male adolescents selling sex were found to have more loneliness and internalized mental health symptoms compared to girls selling sex, and drug abuse was common (Pedersen \& Hegna, 2003). Sexually abusive behaviour has also been associated with boys selling sex (Svedin \& Priebe, 2007). 
However, there are currently few studies concerning male adolescents selling sex, giving a strong female bias in the literature investigating adolescents selling sex (Mitchell et al., 2017).

\section{Motives for selling sex}

In interview studies, adolescents selling sex are described as a heterogeneous group in regard to their motives for selling sex, which vary from pure curiosity to physical force (Bagley \& Young, 1987; Edinburgh et al., 2015; Hwang \& Bedford, 2004; Song \& Morash, 2016; van de Walle et al., 2012). Differences could be seen in the selling of sex being perceived as forced or voluntary (Hwang \& Bedford, 2004; van de Walle et al., 2012), even though there might not be a clear line between the experience of being forced or not forced. Motives for selling sex could be coercion or persuasion by a pimp or a boyfriend (Bagley \& Young, 1987; Edinburgh et al., 2015; Kennedy, Klein, Bristowe, Cooper, \& Yuille, 2007; Rothman, Bazzi, \& Bair-Merritt, 2015) or the influence of senior or junior peers (Bagley \& Young, 1987; Edinburgh et al., 2015; Song \& Morash, 2016). Studies indicate that adolescents who do not have a pimp might experience the selling of sex as more consensual (Edinburgh et al., 2015). For some individuals, selling sex could be a way to obtain shelter for the night or it could constitute the main source of income, while others might see it as a way of receiving money or expensive gifts (Edinburgh et al., 2015; Hwang \& Bedford, 2004; Song \& Morash, 2016; van de Walle et al., 2012).

Other motives for selling sex among adolescents include drug abuse (Bagley \& Young, 1987; Hwang \& Bedford, 2004; Kennedy et al., 2007). However, an interview study of women selling sex during adolescence found that only a few had drug addiction as a motive when starting to sell sex, although many started to use drugs during the period of prostitution (Coy, 2009). In interview studies, selling sex has been seen as a way to get confirmation including feeling appreciated, being touched or being physically close to someone (Hwang \& Bedford, 2004; Jonsson et al., 2015; Rothman et al., 2015). In a Swedish interview study of young women selling sex before 18 years of age, the compensation was described as unimportant and instead the function of selling sex was described as a way to get confirmation and to cope with negative feelings like anxiety (Jonsson \& Svedin, 2012; Jonsson et al., 2015). 
In a study of 45 former prostitutes aged 18-36 years, about 50\% report child sexual abuse as a significant factor behind starting to sell sex. Prostitution was closely associated with earlier exposure to sexual, physical or emotional abuse. In addition to sexual abuse, other reasons for starting to sell sex included a need of money (33\%) or drugs (40\%), being persuaded by a pimp/boyfriend (13\%) and being influenced by friends (13\%). No one in this sample had gained an economic advantage from being prostituted, but many had the experience of sexual, physical or emotional abuse during the period of prostitution (Bagley \& Young, 1987). A similar picture has been found among young women selling sex in Sweden, who reported sexual abuse or other traumatic events as an important factor for starting to sell sex. Sexual abuse was described as a reason for the feeling that the body had been desecrated and had no value, making the selling of sex possible (Jonsson \& Svedin, 2012).

In a Dutch study of 30 young informants aged 14-24 years with the experience of selling sex, the selling was described by some as exciting; however, these informants usually had a high level of education and were not dependent on the income from selling sex. For others, the reward was the most important part of selling sex (van de Walle et al., 2012). Interview studies indicate that males, especially heterosexual males, have more positive experiences of selling sex compared to females, who have more feelings of shame and guilt (van de Walle et al., 2012; Vanwesenbeeck, 2013).

\section{Self-injurious behaviour}

In the last 10-15 years, there has been a growing body of studies investigating self-injurious behaviour (SIB). Historically, several different terms have been used in research for this behaviour. SIB is usually divided up into suicidal and non-suicidal SIB, and could further be divided up into direct and indirect self-injury. The most common terms used today for direct SIB are non-suicidal self-injury (NSSI) and deliberate self-harm (DSH). The term DSH has been used more commonly in Europe and Australia, and also includes suicidal behaviour without fatal outcome and more indirect damage to the body such as severe substance abuse, drug overdose and the ingestion of sharp objects (Brunner et al., 2014; Muehlenkamp, Claes, Havertape, \& Plener, 2012). 
NSSI was suggested as a separate syndrome in need of more research in the $5^{\text {th }}$ edition of the Diagnostic and Statistical Manual of Mental Disorders (DSM) from the American Psychiatric Association (2013), and this term is probably the most commonly used term today. NSSI was defined as self-inflicted damage to the surface of the body without suicidal intention, occurring five times or more during the past year. The motivation should be to relieve negative feelings, resolve interpersonal difficulties or induce positive feelings (American Psychiatric Association, 2013). The most common self-injury described in the literature is cutting and burning the skin (International Society for the Study of Self-Injury [ISSS], 2018). Earlier definitions of SIB have also included more indirect forms of self-injury such as risktaking, promiscuity and drug abuse (Muehlenkamp, 2005), but are currently not usually considered as direct SIB since the tissue damage is seen as an unintended side effect (Klonsky, 2007b; Nock, 2010).

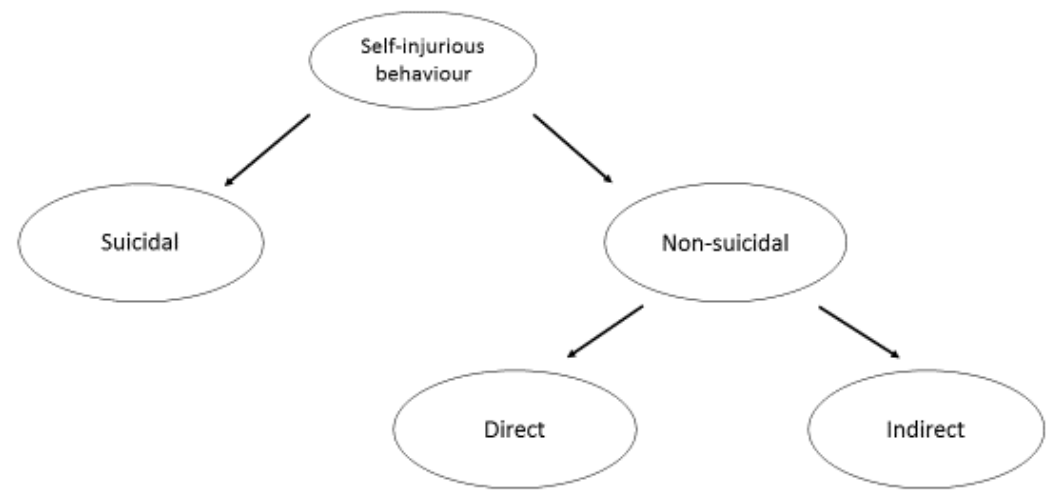

Figure 1. Self-injurious behaviour

Indirect self-injurious behaviour is when the self-injury is an unintended by-product such as risk-taking behaviours, binge eating or substance abuse (Claes \& Vandereycken, 2007; Møhl, La Cour, \& Skandsen, 2014; Nock, 2010). Indirect self-injurious behaviour has been described as an activity that results in unintended harm that does not occur immediately; the behaviour should be repetitive or persistent, of clinical significance and potentially physical harmful over time (St. Germain \& Hooley, 2012). The co-occurrence of suicidal and nonsuicidal self-injurious behaviours as well as direct and indirect self-injury is common (Andover, Holman, \& Shashoua, 2014; Claes \& Muehlenkamp, 2014; Hamza, Stewart, \& 
Willoughby, 2012; Møhl et al., 2014; Nock, 2010). Despite the topographical differences in direct and indirect self-injury, the behaviours do share common elements such as using the body to regulate states of mind and social situations (Brausch \& Muehlenkamp, 2014; St. Germain \& Hooley, 2012; Weiss, Sullivan, \& Tull, 2015).

According to a study of European adolescents (mean age 14.9 years), the prevalence of direct SIB was $27.6 \%$, with $19.7 \%$ reporting to use it occasionally and $7.8 \%$ repeatedly (Brunner et al., 2014). A recent review study found the lifetime prevalence of NSSI among adolescents to be $17-18 \%$, and $1.5-6.7 \%$ met the DSM 5 criteria, but in clinical samples the prevalence of NSSI was as high as $60 \%$ (Brown \& Plener, 2017). The use of NSSI is more commonly seen among females, especially in clinical samples (Bresin \& Schoenleber, 2015). In a Swedish study of adolescents aged $15-17$ years, $11.1 \%$ of the girls and $2.3 \%$ of the boys fulfilled the criteria for NSSI disorder (NSSID) according to DSM-5 (Zetterqvist, Lundh, Dahlstrom, \& Svedin, 2013). Adolescents with a non-heterosexual orientation have been found to be at particularly higher risk of NSSI (Batejan, Jarvi, \& Swenson, 2015).

Suicide is the leading cause of death for young men and women aged 20-30 years. Even though self-injury is often used for non-suicidal purposes, $10 \%$ of all patients who presented at hospital after a self-harming act (including both suicidal and non-suicidal behaviour) committed suicide within 10 years (Butler, 2016). Self-injury is one of the strongest predictors of suicidal ideation and suicide attempts in both longitudinal and cross-sectional studies, and more severe forms of NSSI are especially associated with a higher risk of suicidal behaviour (Hamza et al., 2012). NSSID has been associated with major depression, anxiety disorder, mood disorder bulimia, borderline personality disorder (BPD), internalization, high level of emotional dysregulation, suicide attempts and ideation, and being a victim of abuse (Zetterqvist, 2015). However, sexual abuse has only been moderately linked to NSSI (Brown \& Plener, 2017).

\section{Sex as self-injury}

Sex as self-injury (SASI) is a concept that is yet not accepted in the research field, but it is a behaviour that has been highlighted in Sweden in recent last years (Jenstav \& Meissner, 2016; Jonsson \& Lundström Mattsson, 2012). 
In a Swedish interview study, selling sex was described as a way of self-injuring that became more frequent during periods of poor mental health (Jonsson et al., 2015). For some informants, violent sex including physical pain was used as a way to handle anxiety and was compared to NSSI like cutting or burning the skin. Risk-taking due to not knowing what would happen during a sexual encounter was part of self-injury. During periods of poor mental health, the Internet was used in a different way including more visits to websites concerning self-injury, eating disorders and sex (Jonsson \& Svedin, 2012; Jonsson et al., 2014; Jonsson et al., 2015).

No previous studies have been found to investigate the prevalence of using sex as a means of self-injury. However, selling sex among adolescents has been associated with more risktaking sexual behaviours such as low age of first intercourse, a higher number of sexual partners, having more sexual experience and more sexually transmitted infections (Barnert et al., 2017; Edwards et al., 2006; Pedersen \& Hegna, 2003; Svedin \& Priebe, 2007; Wilson \& Widom, 2010). Several studies have investigated the association between sexual risk-taking and poor mental health. Adolescents with sexual risk-taking behaviours are twice as likely to have a history of suicide attempts (Houck, Hadley, Lescano, Pugatch, \& Brown, 2008). Teenage girls involved in prostitution are 6.8 times as likely to have attempted suicide compared to their peers (Gibbs Van Brunschot \& Brannigan, 2002). In a mixed method study of sexually exploited runaway adolescents, as many as $71 \%$ reported self-injury and $50 \%$ had attempted suicide (Edinburgh et al., 2015). Symptoms of depression predict sexual risktaking behaviours, indicating the use of sex as a coping strategy for depression (Wilson, Asbridge, Kisely, \& Langille, 2010).

\section{The function of self-injury}

Another way to understand SIB is to study the function of the behaviour. This has been investigated in several studies, and the consensus is that self-injury is most commonly used as a means of affect regulation (Ford \& Gomez, 2015; Klonsky, 2007a; Klonsky, Glenn, Styer, Olino, \& Washburn, 2015). The four-factor model proposed by Nock and Prinstein in 2004 is often referred to in relation to the function of NSSI. It includes both automatic reinforcement, such as affect regulation, and social reinforcement, such as getting attention or avoidance. These functions could be both positively and negatively reinforced (Nock \& Prinstein, 2004). The most common function of NSSI among Swedish adolescents is automatic negative and 
positive reinforcement such as stopping bad feelings, reliving feeling numb or empty, punishing oneself and feeling something even if it is pain (Zetterqvist et al., 2013), which is concurrent with other international studies (Brown \& Plener, 2017).

In a theoretical model of self-injury, three main propositions were suggested (Nock, 2009, 2010): 1) Self-injury occurs because it is effective in regard to the function of the behaviour, including affect regulation or the influence of the social environment. 2) The occurrence of self-injury increases because of factors influencing affect regulation/cognitive state or the social environment such as hyperarousal due to stressful events, poor verbal skills or social skills. 3) There are several self-injury-specific factors that lead to the behaviour for the specific person. For these factors there are several theories include e.g. the social learning hypothesis, the self-punishing hypothesis and the pain/analgesia/opioid hypothesis.

\section{Neuropathology and self-injury}

Self-injurious behaviour goes against the natural instinct of protecting the body from harm, instead inducing injury as a means of affect regulation. Self-injury has been found to induce tension reduction. The exact mechanism behind this is not yet completely clear, but physical pain seems to play a central part (Ballard, Bosk, \& Pao, 2010; Bresin \& Gordon, 2013a; Haines, Williams, Brain, \& Wilson, 1995; Reitz et al., 2015). Brain regions that process physical and emotional pain have been found to overlap with those that process painful emotions (Ballard et al., 2010; Eisenberger, 2012). This means that the neuroendocrine responses are the same as those triggered by physical and emotional pain. The endogenous opioid system is important in regard to the reward system and the regulation of pain and affects (Bresin \& Gordon, 2013b). Studies have suggested that endogenous opioids increase during injury and treatment with opioid antagonist decreases the engagement in self-injury, which could be interpreted as treatment reducing the reinforcement value of self-injury since it is no longer experienced as rewarding (Bresin \& Gordon, 2013b). The perception of pain has been suggested to be altered in individuals using self-injury (Ballard et al., 2010; Osuch, Ford, Wrath, Bartha, \& Neufeld, 2014), as well as levels of endogenous opioids (Stanley et al., 2010). 
The most important changes found concerning neurobiological aspects of individuals using self-injury are: 1) altered activity in amygdala and the limbic system, 2) decreased levels of serotonin in the brain, and 3) altered function of the autonomic nervous system and the HPA (hypothalamic-pituitary-adrenal) axis (Cullen, Westlund, LaRiviere, \& Klimes-Dougan, 2013; Kaess et al., 2012; Niedtfeld et al., 2010; Plener, Bubalo, Fladung, Ludolph, \& Lule, 2012; Schulze, Schmahl, \& Niedtfeld, 2016). Some of the changes in the brain in NSSI might however be explained by the co-occurrence of depression (Plener et al., 2012).

\section{Trauma and self-injury}

Most people are exposed to at least one traumatic occurrence during their life, but only a few develop severe symptoms of the trauma such as post-traumatic stress disorder (PTSD) (Kessler et al., 2017). According to a Swedish study of adolescents with a mean age of 17 years, $84.1 \%$ reported the experience of at least one potential traumatic event (Aho, GrenLandell, \& Svedin, 2016). A meta-analysis found that the overall rate for PTSD for children and adolescents exposed to potential traumatic events was $15.9 \%$, and the highest numbers were for girls exposed to interpersonal trauma at 32.9\% (Alisic et al., 2014). In a systematic review of children exposed to war, the pooled estimate to developed PTSD was 47\% (Cl: 35 60\%) (Attanayake et al., 2009).

Post-traumatic stress disorder (PTSD) is, according to the DSM-5 criteria from the American Psychiatric Association (2013), defined as a) exposure to death, danger of life, serious injury or sexual violence to oneself, being witness to it or a close friend or relative having been exposed, b) symptoms of recurrent, unwanted and distressful memories, recurrent nightmares, dissociative reactions, physical and psychological reactions when exposed to signals reminding one of the occurrence, c) avoidance of stimuli associated with the traumatic event, d) negative cognitive state, or e) alterations in affect and impulses such as irritability or aggressive behaviour, self-destructive behaviour, hypervigilance, attention deficit and sleeping disorder (American Psychiatric Association, 2013). However, persons exposed to long-term interpersonal trauma such as child sexual and physical abuse, neglect or polyvictimization have been found to express more complex symptoms of trauma including 1) alteration in regulating affects and impulses including suicidal preoccupation, modulation of anger, sexual involvement, self-injury and risk-taking, 2) dissociation and amnesia, 3) 
somatization, 4) alteration in self-perception including shame and guilt, 5) alteration in personal relations, or 7) alteration in system of meaning including despair and hopelessness (Van der Kolk \& Fisler, 1994; van der Kolk, Roth, Pelcovitz, Sunday, \& Spinazzola, 2005). The diagnosis of complex PTSD has been suggested for inclusion in the new International Classification of Diseases, ICD-11 and for this diagnosis affect dysregulation, negative selfconcept and difficulties in relationships should be present as well as PTSD symptoms (Brewin et al., 2017).

The association between PTSD and self-destructive and sexual risk-taking behaviours has been investigated in several studies (Dixon-Gordon, Tull, \& Gratz, 2014; Ford \& Gomez, 2015; Van der Kolk \& Fisler, 1994). Trauma including sexual assault is especially associated with self-injury including NSSI and suicide attempts (Dixon-Gordon et al., 2014; Ford \& Gomez, 2015; Maniglio, 2011; Van der Kolk \& Fisler, 1994). PTSD and dissociative disorders are associated with the increase of self-injury and suicidal behaviour, emotional dysregulation such as alexithymia, shame and anger (Ford \& Gomez, 2015). Self-injury could induce a vasovagal reaction, including lower blood pressure and heart rate, and has been suggested as a way to induce a dissociative state of mind to oneself (Schauer \& Elbert, 2010).

Exposure to child abuse and neglect could give rise to an inability to modulate emotions, which could be expressed with a range of behaviours like aggression against others, selfdestructive behaviours, eating disorders and substance abuse which should be understood as a way to achieve self-regulation (Van der Kolk \& Fisler, 1994). Self-destructive behaviours, eating disorders and substance abuse could be used as a way to control and modulate emotions, but could also be a way to gain intimacy or acceptance after exposure to trauma (Cook et al., 2005; Van der Kolk \& Fisler, 1994).

Depression and anxiety have been found to be important mediators for using sex as affect regulation and later sexual assault (Littleton, Grills-Taquechel, Buck, Rosman, \& Dodd, 2013; Orcutt, Cooper, \& Garcia, 2005). The physical severity of child sexual abuse is correlated with revictimization, self-blame, PTSD and number of consensual sexual partners (Arata, 2000). 


\section{To confide}

In a Swedish interview study of young women selling sex, the informants had often been in contact with healthcare and social services during their childhood, but a recurrent pattern was that they often felt misunderstood or that they had not been listened to (Jonsson \& Svedin, 2012). This is concurrent with other studies indicating that young people exposed to sexual exploitation are often in contact with healthcare, but few confide their experience of sexual exploitation (Barnert et al., 2017; Greenbaum, 2018). In a Swedish study concerning the disclosure of sexual abuse, it was common to disclose it to a peer and few disclosed it to professionals. In total, $19 \%$ of the girls and $31 \%$ of the boys had not disclosed it to anyone. Girls were less likely to disclose if they had been exposed to contact or penetrative sexual abuse (Priebe \& Svedin, 2008). Important factors for disclosing sexual abuse are being believed, being asked, shame/self-blame, concern for oneself and others, and peer influence. The experience of both wanting to tell and not wanting to tell has been described (McElvaney, Greene, \& Hogan, 2014).

In many countries, prostitution is seen as a criminal act which, of course, is a barrier to seeking help and support (Rand, 2010). The fear of being caught by the police and a sense of feeling judged due to their lifestyle become barriers to seeking healthcare for sexual exploitation (Ijadi-Maghsoodi, Bath, Cook, Textor, \& Barnert, 2018). Further, young people who are exposed to commercial sexual exploitation do not always view themselves as victims until later, making it hard to seek help and support (Rand, 2010).

According interview studies of adolescents selling sex in Sweden, the Internet was used as a means to confide experiences of selling sex since it was found to be hard to talk to someone face-to-face concerning these topics. Feelings of shame and guilt were common, and the fact that selling sex was both something disgraceful and something that was hard to live without made it hard to confide. Many of the informants had experience of help and support from both social services and psychiatric services, but few had confide selling sex. All the informants in the study had a feeling of being misunderstood and that they had not been given the opportunity to be listened to (Jonsson \& Svedin, 2012) 


\section{Aim of the Thesis}

The overall aim of the thesis was to investigate the prevalence of, associated risk factors for and motives for selling sex and the use of sex as a means of self-injury among Swedish adolescents. Further, motives for and manifestations of sex as self-injury were investigated.

\section{Study $I$}

The aim of Study I was to investigate the prevalence of adolescents selling sex in a sample from the third year of Swedish high school collected in 2009. Association with sexual, physical and emotional abuse, self-reported mental health, self-harm behaviour and the experience of help and support were to be investigated with participants as a group and divided up by gender.

\section{Study II}

Study II aimed to investigate adolescents' motives for selling sex in a national sample from the third year of Swedish high school collected in 2014. The aim was to identify groups of adolescents according to their motives for selling sex, and to investigate risk factors associated with underlying motives for selling sex such as gender differences, characteristics of selling sex, trauma symptoms, sexual orientation, sexual abuse, self-injurious behaviours, alcohol and drug abuse.

\section{Study III}

Study III aimed to investigate the self-reported prevalence of using sex as a means of selfinjury (SASI) among a sample of adolescents in the third year of Swedish high school collected in 2014. The study also aimed to investigation the association between SASI and sociodemographic factors, sexual orientation, sexual risk-taking behaviours, emotional, 
physical and sexual abuse, mental health through trauma symptoms, non-suicidal self-injury (NSSI) and the experience of seeking healthcare for psychiatric disorders.

Study IV

The aim of Study IV was to explore experiences of sex as self-injury by using a qualitative method to get an understanding of motives for and manifestations of the behaviour. 


\section{Material and Methods}

\section{Participants}

The thesis was based on three different surveys:

1. Study I was based on the survey 'Youth sex and the Internet', which is a crosssectional national survey from the third year of Swedish high schools that was carried out in 2009. This study was partly a replication of a previous survey from 2004 (Svedin \& Priebe, 2004). The survey included 119 schools and 3498 adolescents participated, corresponding to a response rate of $60.4 \%$. The mean age of the participants was 18.3 years $(\mathrm{SD}=0.6)$.

2. Studies II-III were based on the survey 'Youth sex and the Internet - In a changing world', which was partly a replication of the two previous studies from the third year of Swedish high schools (Svedin \& Priebe, 2004, 2009), The studies included 171 schools and 5839 participants, corresponding to a response rate of $59.7 \%$. The mean age was 18.0 years $(\mathrm{SD}=0.6)$.

3. Study IV used an anonymous web-based, self-selected, open-ended questionnaire including 199 participants (190 female, 4 male and 4 with a nonbinary identification). One person did not report gender identity. The participants were aged 15-64, with a mean age of 27.9 years (SD 9.3). However, most informants had started to use SASI aged 12-19. For the analysis, qualitative content analysis was used (Patton, 2015). 


\section{Procedure}

\section{Studies I-III}

For the national surveys 'Youth sex and the Internet' that was carried out in 2009 and 2014, Statistics Sweden contributed by selecting the study sample and distribution and collecting the questionnaires. To get a representative sample from the third year of Swedish high schools, a cluster sampling was used based on the sizes of schools, geographic distribution in Sweden and study programmes. One or two educational courses were selected from each selected school according to the National School Records for 2007 and 2013 when students attended the second year of high school (see Figure 2).

Written information about the study was sent to the principals of the schools by mail before the study by Statistics Sweden, and was given to the students before answering the questionnaire. The distribution and selection of the questionnaires was carried out by Statistics Sweden in the spring of 2009 and the autumn of 2014. The questionnaire was answered anonymously during lesson time using pen and paper in 2009 and using computers (165 schools) or paper copies (six schools) in 2014. Informed consent for participation was given by the adolescents by filling in the questionnaire.

For the 2014 study, an additional sample from Stockholm County was included in the study. This sample was selected using the same selection criteria. The sample from Stockholm County had a lower response rate compared to the country as a whole (48.7\% vs $65.3 \%)$, respondents were more often attending medium-size schools $\left(51.2 \%\right.$ vs $41.6 \%, \chi^{2}=63.6, d f$ $=2, p<.001$, Cramer's $\mathrm{V}=.10$ ) and were more often following practical study programmes $\left(33.2 \%\right.$ vs $27.7 \%, \chi^{2}=17.1, d f=1, p<.001$, Cramer's V $\left.=.05\right)$. However, these findings only had a small effect size which is why the sample was included in the studies.

\section{Study IV}

In Study IV, the informants were recruited via the websites and social media channels of NGOs offering help and support to woman and young people. In total, 37 NGOs agreed to publish the link to the survey on their websites, and most of these were women's shelter and empowerment centres for girls and women (in Swedish: Tjej-och Kvinnojourer), see acknowledgments. No compensation was offered to the participants or organizations involved. 
Selection based on the National

School Register from the 2nd

year of Swedish high school

2007

2013

150

261 schools

7700

13903 students

\section{Loss of schools due to}

- The school no longer existed

- The study course was no longer given by the school

- Schools did not respond

- Did not want to participate

- Were unable to participate

\section{Number of schools that}

agreed to participate

$\begin{array}{ll}\mathbf{2 0 0 9} & \mathbf{2 0 1 4} \\ 119 & 171 \text { schools } \\ 5792 & 9773 \text { students }\end{array}$

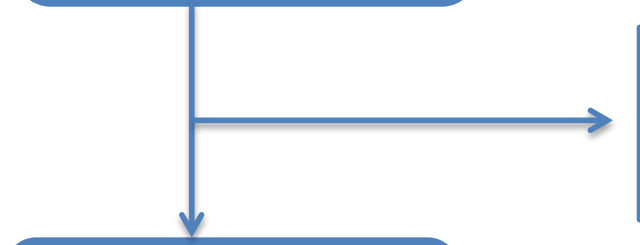

\section{Loss of students due to:}

- Did not want to participate

- Was not at school the present day

Number answering

$2009 \quad 2014$

$119 \quad 171$ schools

$3503 \quad 5873$ students

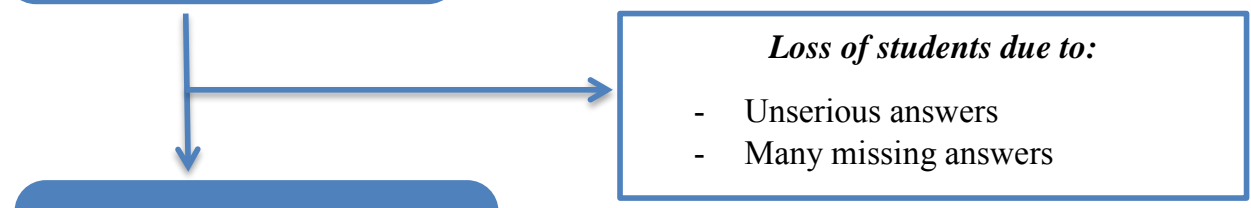

Final number of participants

$2009 \quad 2014$

$119 \quad 171$ schools

$3498 \quad 5839$ students

Figure 2. The selection and loss of study sample for Studies I-III 
The survey was advertised as follows: 'Do you have experience of sex as self-injury and are over 15 years of age? Do you want to participate in an anonymous questionnaire-based study in order to increase understanding of SASI and improve help and support? Click on this link.' Those who were interested in participating were directed to information about the study, including the aim of the study, contact information for the researchers and contact information for help and support if needed after answering the questionnaire. Consent to participate was given by filling in the questionnaire. The questionnaire included a short introduction repeating the inclusion criteria of being over 15 years of age and having experience of using SASI, and presenting the definition of SASI for the study as follows: 'That you have repeatedly sought sexual situations that have caused you physical and/or mental harm and that have affected you in your life'. The survey was published from December 2016 to April 2017 and was public meaning, that anyone could answer it. To collect the answers, the web-based software Survey and Report (Artologik) was used. All answers were reviewed after collection in regard to reliability, and all answers were considered trustworthy.

\section{Measures}

\section{Studies I-III}

The questionnaires used for Studies I-III included a total of 88 questions (the 2009 survey) and 116 questions (the 2014 survey). The questionnaires covered the following areas:

1) Sociodemographic data

2) Lifestyle and health

3) Consensual sexual experiences

4) Experience of emotional, physical and sexual abuse

5) Use of the Internet and mobile phones, and online harassment

6) Experience of selling sex

7) Use of pornography

8) Experience of seeking help and support

9) Symptoms of trauma (added in 2014)

10) Self-injurious behaviours including SASI (added in 2014) 
To investigate adolescents' experience of selling sex, the question used was 'Have you ever sold sexual services?' with yes/no answer options. This question was followed by questions concerning the kind of compensation, the means of contact with the buyer, the number of times sex had been sold and the age of the buyer. Motives for selling sex were investigated by using a modified version of a questionnaire previously used in a Swedish study of adult prostitution (Kuosmanen, 2008).

A new question was formulated concerning experiences of using sex as self-injury in the 2014 survey. It was formulated as 'Have you ever used sex to intentionally hurt yourself?' giving a yes/no answer option. This was followed by questions concerning age when first using SASI, number of times using SASI ever and during the last year, age and gender of the sexual encounter on the most recent occasion and perceived pain during the SASI.

To investigate the function of SASI, the Functional Assessment of Self-Mutilation (FASM) (Lloyed, Kelley, \& Hope, 1997) was used. The FASM includes 22 statements assessing the function of NSSI with the answers never, rarely, sometimes and often. Earlier studies have showed acceptable psychometric properties for adolescents (Esposito, Spirito, Boergers, \& Donaldson, 2003; Penn, Esposito, Schaeffer, Fritz, \& Spirito, 2003) and FASM has also been tested in a Swedish study of adolescents with NSSI (Zetterqvist et al., 2013), but it has never been tested for SASI. The FASM instrument was added as follow-up questions for both NSSI and SASI, but in relation to SASI two further statements were added: 'To get attention from the one you have sex with' and 'Because you don't like your body'.

To investigate non-suicidal self-injury in the 2014 survey, a question was included from the Self-Injurious Thoughts and Behaviors Interview (Nock, Holmberg, Photos, \& Michel, 2007) and was formulated as 'Have you ever actually engaged in self-injury without the intention of suicide? (That is, intentionally hurt yourself without wanting to die, e.g. by cutting or burning yourself)', giving a yes/no answer option.

The question concerning gender was formulated as 'Are you a... a) man, b) woman or c) this classification does not fit me'. Sociodemographic factors were investigated using questions concerning parents' occupation and education, financial situation in the family, immigrant background and living situation. 
Questions concerning sexual behaviours and sexual risk-taking included sexual orientation, voluntary sexual experiences, age at first instance of voluntary sexual intercourse, number of sexual partners ever, use of contraceptives, experience of abortion and sexually transmitted chlamydia infection.

The experience of sexual abuse was investigated using the question 'Have you been exposed to any of the following against your will?' including the following answer options:

a) Someone having exposed himself/herself to you via the Internet or otherwise (only included in the 2014 study)

b) Someone have touched your genitals/tried to undress you to have sex with you

c) You have masturbated for someone

d) You have had vaginal intercourse

e) You have had oral intercourse

f) You have had anal intercourse

Follow-up questions included the number of times the person had been exposed to sexual abuse, age and the type of sexual abuse at the first occurrence, and the relationship to the perpetrator.

Emotional and physical abuse was measured using the question 'Have you been subjected to any of the following by an adult prior to the age of 18 ?', including three answer options for emotional abuse: a) insults, b) threats of violence and c) isolation from friends. Physical abuse included eight answer options covering experiences of being pushed or shaken, having had things thrown at, being kicked or beaten with hands, fists or weapons, being burned or choked. The answers ranged from $1=$ 'never' to $4=$ 'often'.

Mental health was measured in the 2009 survey used the Swedish version of the Hopkins Symptoms Checklist- 25, HSCL-25 (Nettelbladt, Hansson, Stefansson, Borgquist, \& Nordström, 1993) which measures depression and anxiety symptoms during the previous week. The instrument is a shorter version of SCL-90 (Derogatis, 1983), and has been used and validated in several studies (Nettelbladt et al., 1993; Sandanger et al., 1999; Strand, Dalgard, Tambs, \& Rognerud, 2003). Cronbach's alpha for the present study was 0.93. Two questions concerning self-harm were added to the end of HSCL-25, formulated as 'Have you wanted to harm yourself?' and 'Have you harmed yourself?', and concerned experiences during the preceding week. 
To measure trauma symptoms, the Trauma Symptom Checklist for Children (TSCC) was used (Briere, 1996). The instrument includes 54 items that can be divided into the following subscales: anxiety, depression, post-traumatic stress (PTS), dissociation, anger and sexual concerns. The instrument has been translated and validated in Sweden for the age group 1017 years. In a validation study, Cronbach's alpha was found to be .94 for the total scale and 0.78-0.83 for the subscales (Nilsson, Wadsby, \& Svedin, 2008). Cronbach's alpha for the Studies II and III was 0.95 for the total scale and as follows for the subscales: 0.82 for anxiety, 0.88 for depression, 0.87 for PTS, 0.85 for dissociation, 0.84 for anger and 0.65 for sexual concerns.

A new question was formulated for the survey of 2014 concerning contact with healthcare for psychiatric disorders, and was formulated as: 'Have you ever been in contact with healthcare services for...' giving the following answer options: a) depression/anxiety, b) eating disorders, c) ADHD/ADD or similar, d) autism/Asperger's, e) suicide attempt and f) alcohol/drug abuse.

Alcohol binge drinking was investigated using the question: 'Think about the last 12 months. How often have you, on a single occasion, drunk alcohol comparable to four large cans of strong beer/cider or $25 \mathrm{cl}$ liquor or a bottle of wine or six cans of medium-strength beer?' This question has previously been used by the Public Health Agency of Sweden. Use of drugs was investigated using the question: 'Have you used any of the following?' including the options a) cannabis, b) psychostimulants like cocaine or amphetamine, c) opiates e.g. heroin, d) Internet drugs like Spice, mephedrone, MDPV or Kratom, e) GHB or anabolic steroids, and f) ecstasy.

The question concerning help and support for the 2009 survey was formulated as 'Have you on any occasion sought help and support for any of the items below?', including several answer options, of which 'selling sexual services' was one. Two follow-up questions were included. One was formulated as 'Where did you seek help and support', including the answer options peers, parents, older relatives of friends, professional (e.g. psychologist), through the Internet, NGOs, helplines such as BRIS, and other. The other follow-up question was 'Have you received the help and support that you needed', and the answer was rated on a five-grade scale from 'Yes, it was very good' to 'No, I did not get any help'. 
Study IV

All questions used for Study IV were formulated for the survey based on experiences from previous research concerning SASI (Fredlund, Svedin, Priebe, Jonsson, \& Wadsby, 2017; Jenstav \& Meissner, 2016; Jonsson \& Lundström Mattsson, 2012). The questionnaire was tested in a pilot study including five informants in October 2016 and was slightly changed after that.

The questionnaire comprised twelve open-ended questions, see Appendix. The first two questions concerned the age and gender of the informant. The experience of SASI was investigated using the question 'Tell about your experiences of sex as self-injury':

a) 'In what way did you have sex as self-injury?'

b) 'How did it start?'

c) 'How old were you when you had sex as self-injury? Do you still have it?'

d) 'What made it continue?'

e) 'Tell about a typical occasion when you had sex as self-injury. What happened?'

f) 'Think of a typical occasion. If this happened with another person, what relationship did you have to the other person and what was his or her age and gender?'

g) 'If you have stopped, what made you stop?'

The questionnaire also included two questions concerning the experience of help and support, but these questions and the questions concerning to stop using SASI will be analysed in an additional study. One question concerning coping strategies for negative feelings and occurrences was partly analysed when including information about motives and manifestations of SASI. The question 'In which way did you have sex as self-injury?' was added to the questionnaire two weeks into the survey to get a better description of the manifestation of SASI, and hence the first 61 participants did not have the possibility to answer this question. 


\section{Data analysis}

Statistical Package for the Social Sciences (SPSS) versions 18.0-23.0 were used for statistical analysis in Studies I-III. Categorical data were analysed using Chi-square and Fisher's Exact test. The Mann-Whitney $U$-test was used for ordinal data, Student's t-test for comparisons of means and, in Study I, multiple linear regression analysis was used to investigate the variance of explanations for independent variables. Forward stepwise binary logistic regression was used in Study III to produce a model for the most important factors associated with SASI. The significance level used in all studies was $p$-value $<.05$.

To investigate underlying motives for selling sex in Study II, an exploratory factor analysis with maximum likelihood extraction and oblique rotation (direct oblimin) was used. The number of factors for the model was decided on according to the scree plot, the Eigenvalues and the clinical relevance of the factors. The factor groups were based on the pattern matrix (the unique contribution of each variable to the corresponding factor) and a structure matrix (the total relationship between each variable and the corresponding factor). Hierarchical cluster analysis was used as support to find groups of adolescents according to the response pattern of the underlying motives for selling sex. The final groups of adolescents were compared, one group against the other two combined for gender, characteristics of selling sex and risk factors, see Figure 3.

In Study IV, content analyses were used to explore the data and to find patterns and themes (Patton, 2015). The text was first read through and coded by Cecilia Fredlund (CF) and Linda Jonsson (LJ) separately, and was later discussed together. Meaning bearing units were later identified by $\mathrm{CF}$ and put into a coding scheme according to the initial coding and new findings. The coding scheme was read through separately by CF and LJ and later discussed together for internal homogeneity and external heterogeneity. This was carried out by 'extension' (going deeper into patterns and themes), 'bridging' (connecting different patterns and themes) and 'surfacing' (finding new categories) until saturation of patterns and themes was achieved. Tables were produced including the main patterns and themes and the number of participants reporting them, to get a feeling of the recurrence of the patterns in the text. 


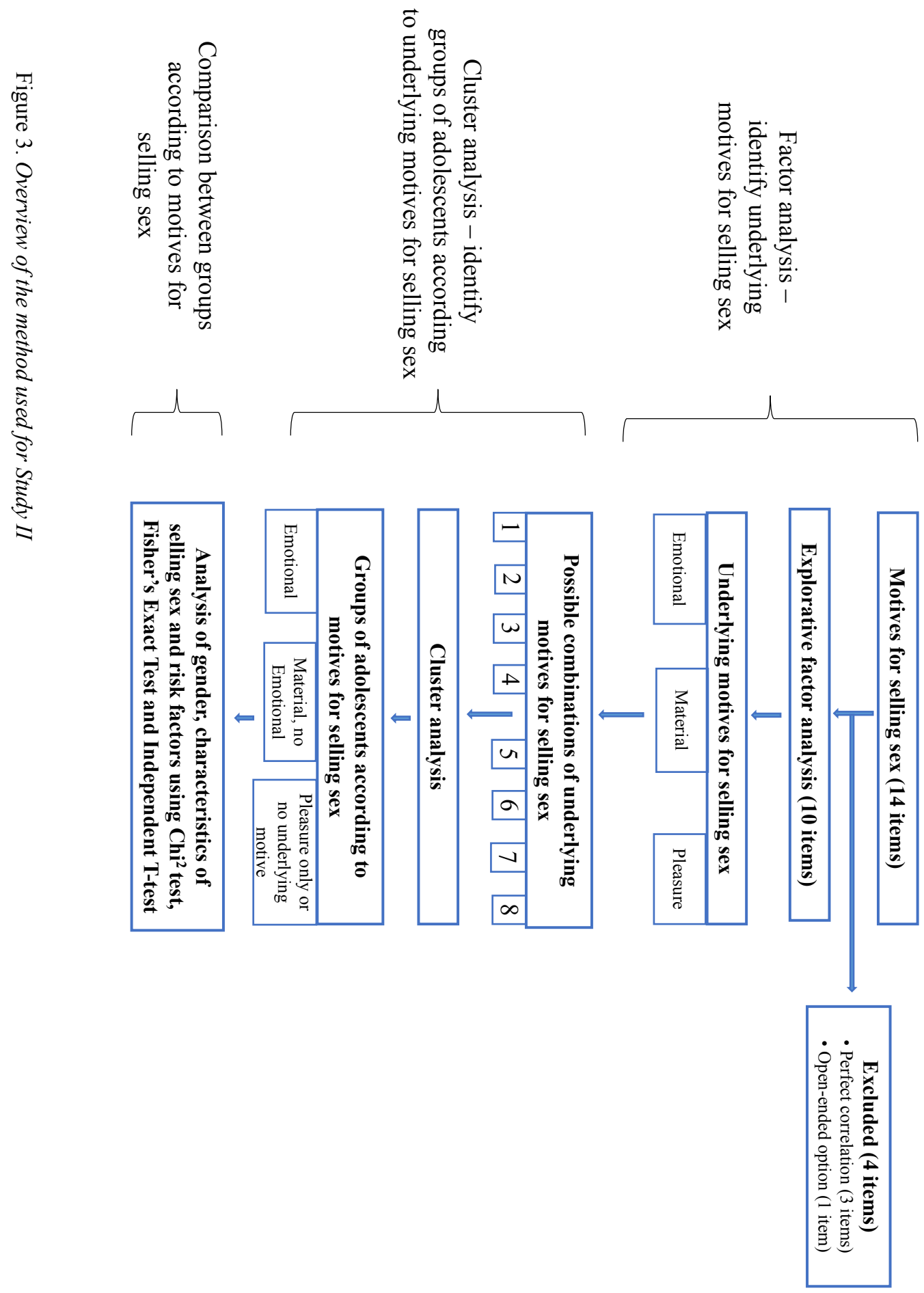




\section{Ethical considerations}

The studies included in the thesis were performed according to the Declaration of Helsinki (World Medical Association, 2017) and were ethically approved by the Regional Ethical Review Board of Linköping University - Dnr. 220-08 (Study I), Dnr. 131-31 (Studies II-III) and Dnr. 386-31 (Study IV).

All four studies included only participants over 15 years of age, since participants above this age are considered by Swedish law to be able to make their own decision on whether or not to participate in questionnaire-based studies, hence parental consent is not needed (the Ethical Review Act of Sweden, 2003, SFS 2003:460).

In all four studies, an information letter concerning the study was given to all participants before answering the questionnaires, including information about the study being voluntary and anonymous. Informed consent to participate was given by filling in the questionnaire. No questions were included concerning personal data or information that could reveal the participants' identity. All answers were answered anonymously in regard to the sensitive questions involved. This leads to the sensitive ethical issue that we did not have the possibility to follow up on individuals reporting high levels of distress. However, all three surveys included information in regard to help and support if needed after answering the questionnaire.

An ongoing discussion concerns whether or not sensitive questions such as questions concerning abuse, sexuality and self-injury can increase discomfort or increase self-injurious behaviour among vulnerable adolescents. However, studies indicate that sexually abused adolescents do not feel increased discomfort when answering questions concerning sexuality and sexual abuse (Priebe, Bäckström, \& Ainsaar, 2010) and that asking adolescents questions concerning suicidal ideation or self-injury does not induce a negative mood; in fact, according to a recent review, it has small beneficial effect on lowering self-injury (Blades, Stritzke, Page, \& Brown, 2018; Deeley \& Love, 2010). 


\section{Funding for the studies}

The 2009 survey 'Youth sex and the Internet' was carried out at the request of the Swedish Ministry of Health and Social Affairs through the Swedish Agency for Youth and Civil Society. The survey was financed by the ministry.

The survey 'Youth, Sex and the Internet - In a Changing World' was carried out at the request of the Swedish Ministry of Health and Social Affairs through the Child Welfare Foundation Sweden and Stockholm County. The survey was financed by the ministry and Stockholm County.

Study IV did not receive funding, but was carried out with support from Stockholms Tjejjour. 


\section{Results of the Empirical Studies}

\section{Studies I-II - Adolescents selling sex}

According to the findings of Study I, $1.5 \%(n=51)$ of the adolescents from the third year of Swedish high schools reported experiences of selling sex for compensation at any occasion and more than half of the adolescents selling sex had done this repeatedly (58\%). More boys than girls had the experience of selling sex (1.7\% vs $1.2 \%)$, but the differences were not statistically significant. In Study II, the prevalence of adolescents selling sex was found to be $0.9 \%(\mathrm{n}=51)$. In this study, more boys $(1.2 \%)$ than girls $(0.6 \%)$ had experience of selling sex $\left(\chi^{2}=6.9, d f=1, p=.009\right)$.

Selling sex among adolescents was associated with sexual abuse, which was seen among all of the girls and $60 \%$ of the boys. In total, almost $80 \%$ of the girls and almost $30 \%$ of the boys had been exposed to penetrative sexual abuse including vaginal, oral and anal sexual abuse. Selling sex was also associated with emotional and physical abuse by an adult during childhood, poor mental health and self-injurious behaviour. During the preceding week, about $42 \%$ of the adolescents had used self-injury to some extent and about $17 \%$ to an extreme extent. According to the logistic regression, the selling of sex was dependent not on gender but on the experience of sexual, physical and emotional abuse, poor mental health and selfinjurious behaviour. Only $32 \%$ of the boys and about $14 \%$ of the girls had sought help and support for the effects of selling sex. It was more common among adolescents selling sex to have sought help and support for other problems and worries such as problems with parents, sexual orientation, emotional, physical and sexual abuse, sexual violence against others, mental health problems and problems related to the Internet. One third turned for help and support to peers such as friends, siblings or partners, and one third turned to professionals such as psychologists. Even though the adolescents selling sex had sought more help and support for different problems and worries, they were not as satisfied with the help and support that they had received compared to peers. 
In Study II, three underlying motives for selling sex among adolescents were found:

Factor 1 -Emotional reasons including the options 'Wanted closeness', 'To feel appreciated', 'Did not feel mentally well/To reduce anxiety' and 'The buyer persuaded me'. This was the most important factor, explaining $32 \%$ of the variance.

Factor 2 - Material reasons included the motives 'Needed money' and 'Needed drugs'. However, the item 'Needed money' loaded on Factors 2 and 3 in both the Pattern Matrix and the Structure Matrix, but according to clinical relevance it was decided this should be kept with Factor 2. Material reasons explained $17 \%$ of the variance.

Factor 3 - Pleasure included the motives 'Fun/exciting', 'Like to have sex', 'Influenced by peers/partners' and 'Affected by alcohol or drugs', and explained $11 \%$ of the variance.

Ten informants did not report any of the three underlying motives for selling sex, but some of these reported open-ended answers as motives for selling sex.

Since adolescents had the possibility to report several motives for selling sex, there were eight possible combinations of underlying motives for selling sex. Hierarchical cluster analyses were used as support to find groups of adolescents according to underlying motives for selling sex. Ultimately, three groups were identified: 1) Adolescents with emotional reasons with or without other reasons, 2) Material reasons with or without Pleasure but no Emotional reasons, and 3) Pleasure only or no underlying motive for selling sex. These three groups were analysed in regard to risk factors.

Adolescents with Emotional reasons for selling sex were found to have an equal gender distribution, and money was the most common compensation for this group (47.4\%). However, compared to the other adolescents selling sex, it was more common for this group to receive material things as compensation $(36.8 \%$, Fisher's Exact Test, $p=.030)$. Contact with the buyer was often made through the Internet (57.9\%), the buyers were often over 25 year of age (73.7\%) and the selling of sex had often occurred more than five times $(42.1 \%)$. Compared to the other adolescents selling sex, adolescents with emotional reasons had more often been exposed to sexual abuse $\left(82.4 \%, \chi^{2}=4.0, d f=1, p=.047\right)$, used SASI to a greater extent $\left(52.6 \%, \chi^{2}=9.6, d f=1, p=.002\right)$ and had a heterosexual orientation to a lower extent $\left(42.1 \%, \chi^{2}=4.4, d f=1, p=.035\right)$. In total, $47.4 \%$ had been exposed to penetrative sexual abuse and $52.6 \%$ had used NSSI. 
Adolescents with Material but no Emotional reasons for selling sex had an equal gender distribution. This group had more often received money as compensation $\left(91.7 \%, \chi^{2}=15.1 d f\right.$ $=1, p<.001)$ and had buyers over 25 years of age more often $\left(83.3 \%, \chi^{2}=4.5, d f=1, p=\right.$ .034) compared to other adolescents selling sex. The means of contact with the buyers was often the Internet (63.6\%), and the selling was often repeated (91.7\%). Sexual abuse (63.6\%) including penetrative sexual abuse (63.6\%) was common, as was NSSI (41.7\%). However, only $16.7 \%$ used SASI and $50 \%$ had a heterosexual orientation.

Adolescents with Pleasure only or no underlying motive reported for selling sex were more often male $(80 \%)\left(\chi^{2}=4.1, d f=1, p=.044\right)$. The group had received money as compensation $\left(10 \%, \chi^{2}=14.7, d f=1, p<.001\right)$, used the Internet as a means of contact $\left(25 \%, \chi^{2}=5.9, d f=1, p=.015\right)$, had buyers over 25 years of age $\left(25 \%, \chi^{2}=13.6, d f=1, p<\right.$ $.001)$, used sex as self-injury $\left(10.0 \%, \chi^{2}=5.0, d f=1, p=.025\right)$ and had been exposed to penetrative sexual abuse $\left(20.0 \%, \chi^{2}=5.1, d f=1, p=.024\right)$ to a lower extent compared to other adolescents selling sex. In total, $52.9 \%$ had sold sex only once and heterosexual orientation was more common in this group $\left(85.0 \%, \chi^{2}=8.1, d f=1, p=.004\right)$. Exposure to sexual abuse (47.4\%) and NSSI (25\%) was less frequent, but not significantly so in this group. There were no differences between the groups concerning alcohol binge drinking, drug abuse and trauma symptoms.

\section{Studies III-IV - Sex as self-injury}

Study III found that $3.2 \%(n=100)$ of the girls, $0.8 \%(n=20)$ of the boys and $9.4 \%(n=5)$ of the adolescents with non-binary identification in the third year of Swedish high school, in total $2.2 \%(\mathrm{n}=125)$, reported having used sex to intentionally hurt themselves on at least one occasion. In total, $70.7 \%$ of the girls and $55.6 \%$ of the boys reported having perceived pain during the SASI. The sex partners were most commonly aged 15-25 years and of the opposite gender.

Adolescents using SASI lived in families with generally poorer financial situations and fewer lived with two parents compared to their peers. Otherwise, few differences were seen in sociodemographic factors such as parents' education and employment, immigrant background or studying theoretical or practical programmes. The behaviour was associated with non-heterosexual orientation, sexual risk-taking behaviour, emotional, physical and 
sexual abuse, high scores for trauma symptoms, NSSI and contact with healthcare for psychiatric disorders. In total, $75 \%$ had been exposed to sexual abuse, and $48.4 \%$ to penetrative sexual abuse. In those cases when sexual abuse had occurred, $91 \%$ had preceded the use of SASI. In total, $65.6 \%$ reported having used NSSI and $61.0 \%$ had sought healthcare for depression/anxiety, $31.4 \%$ for suicide attempts and $28.8 \%$ for eating disorders. According to a forward stepwise logistic regression, the most important factors explaining SASI were selling sex, sexual and physical abuse, NSSI, trauma symptoms for depression and dissociation, and healthcare for depression/anxiety and eating disorders.

As shown in Table 1, the most common function reported for SASI was 'To relieve feeling numb or empty’ (70\%), 'To punish oneself' (65.5\%), ‘To stop bad feelings' (63.6\%), 'Because you don't like your body' (58.6\%), 'To feel something, even if it was pain' $(52.9 \%)$, 'To get control of a situation' $(49.6 \%)$ and 'To get attention from the one you have sex with' $(46.2 \%)$.

Study IV investigated motives for and manifestations of SASI in a self-selected sample with a mean age of 27.9 years $+/-9.3$ years. The majority of the study participants $(82.9 \%)$ had started to use SASI during adolescence, aged 12-19, see Table 2.

Table 2 Background data for Study IV

\begin{tabular}{|lc|}
\hline \multicolumn{2}{|l|}{$n$} \\
\hline Total number of participants & 199 \\
\hline Gender & \\
Female & 190 \\
Male & 4 \\
Non-binary & 4 \\
\hline Age & \\
$15-19$ years & 27 \\
$20-40$ years & 151 \\
$41-64$ years & 19 \\
\hline Age when starting to use SASI & \\
Before 12 years & 8 \\
12-19 years & 165 \\
After 20 years & 21 \\
\hline
\end{tabular}


Table 1 The function of sex as self-injury (SASI)

Investigated by using FASM (Lloyed et al., 1997) and two added questions divided according to the earlier studies (Dahlström, Zetterqvist, Lundh, \& Svedin, 2015; Jonsson et al., 2017)

\begin{tabular}{|c|c|}
\hline & $\begin{array}{c}\% \\
(n=117-122)\end{array}$ \\
\hline \multicolumn{2}{|l|}{ Automatic functions } \\
\hline To relieve feeling numb or empty & 70.0 \\
\hline To feel something, even if it was pain & 52.9 \\
\hline To get control of a situation & 49.6 \\
\hline To punish yourself & 65.5 \\
\hline To stop bad feelings & 63.6 \\
\hline To feel relaxed & 38.1 \\
\hline \multicolumn{2}{|l|}{ Social influence } \\
\hline To get attention & 33.9 \\
\hline $\begin{array}{l}\text { To try to get a reaction from someone, even if it's a } \\
\text { negative reaction }\end{array}$ & 33.3 \\
\hline To receive more attention from your parents or friends & 11.0 \\
\hline To get other people to act differently or change & 16.1 \\
\hline To let other know how desperate you are & 19.5 \\
\hline To get parents to understand or notice you & 6.8 \\
\hline To get help & 12.8 \\
\hline To make others angry & 8.5 \\
\hline \multicolumn{2}{|l|}{ Peer identification } \\
\hline To be like someone you respect & 5.1 \\
\hline To feel more part of a group & 4.3 \\
\hline To give you something to do when with others & 10.2 \\
\hline \multicolumn{2}{|l|}{ Avoiding demands } \\
\hline To avoid school, work, or other activities & 11.5 \\
\hline $\begin{array}{l}\text { To avoid having to do something unpleasant you don't } \\
\text { want to do }\end{array}$ & 15.3 \\
\hline To avoid being with people & 14.5 \\
\hline To avoid punishment or paying the consequences & 11.9 \\
\hline To give yourself something to do when alone & 27.1 \\
\hline \multicolumn{2}{|l|}{ Added questions } \\
\hline To get attention from the one you have sex with & 46.2 \\
\hline Because you don't like your body & 58.6 \\
\hline
\end{tabular}


For the manifestations of SASI, three main themes were found: 1) Psychological harm in sexual situations, 2) Sexual situations including physical harm, and 3) Deliberate search for contact.

SASI was described as deliberate or self-inflicted sexual situations that could include physiological and/or physical harm. It could involve having sex without attraction to, interest in or desire for the other person, using sex as a way of punishing oneself or agreeing to everything in a sexual encounter despite the inner feeling of not wanting to. SASI could involve having physical violent sex including pain. The situations of SASI were sometimes compared to rape situations, but the person described some kind of control in the situation of SASI or that the situation was somehow self-inflicted by e.g. exposing oneself to dangerous situations. The contact of SASI was described as active or deliberate by e.g. making contact through the Internet, at parties or via dating sites. SASI could include selling sex, having sex with many different sex partners or having sex in a relationship. A recurrent pattern for the sexual encounter was older men (more than 10 years older), but all ages were described as well as sexual encounter with females. Some informants described using SASI in masturbation by e.g. cutting or hurting the genitals or repeating things to oneself that had experienced earlier in e.g. a rape situation.

In relation to motives for using SASI, three main themes were found: 1) Regulation of negative feelings, 2) Could not stop, and 3) To get confirmation.

SASI was used as a way to regulate negative feelings such as anxiety. Many reasons for poor mental health were found, but earlier sexual abuse was recurrently mentioned as a starting point. SASI was described as a way to control the situation or a way to handle negative feelings in relation to the body after sexual abuse. SASI was compared to other kinds of SIB, but was sometimes preferred since it was considered by the participants to be less visible and resulted primarily in mental scars rather than visible scars in NSSI. Informants found it hard to stop using SASI, and described it as addictive and compulsive. Negative feelings was described as being relieved during SASI, but could return even stronger afterwards, resulting in a vicious circle. Some study participants described a need for more and more destructive actions, boosting a vicious loop. Other motives for using SASI were to receive positive confirmation, feeling skilled at something (sex) or getting attention and closeness. However, SASI was also used as a way to confirm self-contempt, and being treated badly made sense of the inner feelings of self-hatred. 


\section{General Discussion}

Summary and strengths - adolescents selling sex

Studies I and II are two important studies in regard to understanding the behaviour of adolescents selling sex in welfare countries such as Sweden. The studies found that about $1 \%$ of Swedish adolescents from the third year of Swedish high school have experiences of selling sex for compensation. This is in line with earlier research, but there are still only a few population-based studies available in the world concerning the prevalence of adolescents selling sex, which is why these studies are important (Edwards et al., 2006; Kaestle, 2012; Lavoie et al., 2010; McNeal \& Walker, 2016; Mossige et al., 2007; Pedersen \& Hegna, 2003; Svedin \& Priebe, 2007). Adolescents' motives for selling sex have not previously been investigated in a population-based study, making Study II unique in its design. This study is important in order to understand the occurrence of adolescents selling sex in welfare countries such as Sweden, and to be able to give proper help and support. The study indicates that adolescents selling sex are a heterogeneous group in regard to motives for selling sex, but emotional reasons, material reasons and pleasure are important underlying reasons for adolescents selling sex in Sweden.

The studies confirmed earlier research indicating that boys are an important part of adolescents selling sex, which is often in opposition to the general awareness within society (Kaestle, 2012; McNeal \& Walker, 2016; Mossige et al., 2007; Moynihan et al., 2018; Pedersen \& Hegna, 2003; Svedin \& Priebe, 2007). Further, Study II might help us to understand the gender bias that has been seen in the existing literature regarding adolescents selling sex, where boys are seldom seen in clinical samples (Mitchell et al., 2017; Moynihan et al., 2018). Study II found that there is a difference between boys and girls concerning selfreported motives for selling sex. This means that more boys compared to girls had pleasure motives only or no underlying motive for selling sex. This group of adolescents often sell sex to peers and is not exposed to penetrative sexual abuse as much as other adolescents selling 
sex. These boys might sell sex more as an exploration of sexual behaviours rather than being a victim of child sexual exploitation. However, it has to be kept in mind that even if boys have more pleasure motives or no underlying motive to sell sex, the proportions of boys and girls were equally distributed for emotional reasons only and material reasons with no emotional reasons in Study II. This means that boys selling sex must still be seen as a group that is at risk of sexual exploitation, even though more boys than girls sell sex for motives such as pleasure and fun. Further, even though the motives were pleasure and fun, trauma symptoms were more common among the adolescents selling sex compared to the general population, indicating a group with poor mental health. Further, adolescents have described in interviews that selling sex could start with the motives of pleasure and fun, but other motives were more present later on (Jonsson \& Svedin, 2012; Jonsson et al., 2015).

Selling sex among adolescents had a strong association with the experience of sexual, physical and emotional abuse in the two studies, and sexual abuse was especially seen among adolescents with emotional or material reasons to sell sex. As many as $100 \%$ of the girls selling sex in the study from 2009 had been exposed to sexual abuse. These finding were not surprising, since several earlier studies have shown the association between adolescents selling sex and sexual, physical and emotional abuse (Abelsson \& Hulusjö, 2008; Bagley \& Young, 1987; Farley, 2003; Kaestle, 2012; Lavoie et al., 2010; Pedersen \& Hegna, 2003; Roe-Sepowitz, 2012; Svedin \& Priebe, 2007). The strong association with sexual abuse, poor mental health, self-injurious behaviour and the emotional motives for selling sex indicate that adolescents in Sweden are selling sex as a way to control poor mental health and that sex is used as a means of affect regulation, which has been described in an earlier Swedish interview study (Jonsson et al., 2015). This is a way of understanding prostitution that makes sense of what kind of help and support is needed for the individuals involved. If adolescents in Sweden sell sex as a means of self-injury, the person selling sex could not only be viewed as a victim of violence but is also in need of help and support in regard to affect regulation in order to be able to escape the behaviour.

Study II also found that material reasons, such as a need for money or drugs, were important motives for selling sex among adolescents in Sweden. Money or drugs as motives for selling sex has been described in earlier interview studies of adolescents and young people (Bagley \& Young, 1987; Edinburgh et al., 2015; Hwang \& Bedford, 2004; Kennedy et al., 2007; Song \& Morash, 2016; van de Walle et al., 2012). Concerning this group, it is important to highlight the risk of further prostitution in adulthood that has especially been associated with 
drug addiction (Clarke, Clarke, Roe-Sepowitz, \& Fey, 2012). Childhood emotional abuse, having run away from home and dissociation are especially associated with selling sex before the age of 18 , and entering prostitution as an adult has been more associated with drug and alcohol addiction (Clarke et al., 2012). In contrast to adolescents selling sex for emotional reasons, this group did not use sex as a means of self-injury to the same extent, but they were often exposed to sexual abuse.

Adolescents selling sex are - according to this thesis, but also according to earlier studies - a vulnerable group with symptoms of distress and poor mental health (Bagley \& Young, 1987; Barnert et al., 2017; Heilemann \& Santhiveeran, 2011; Svedin \& Priebe, 2007), which is why it is important to investigate the perceived help and support. Study I found that adolescents selling sex seek more help and support for different problems and worries compared to their peers, which is concurrent with prior studies (Barnert et al., 2017). However, adolescents selling sex were not as satisfied with the help and support that they had received compared to their peers. In a Swedish interview study, adolescents selling sex have described to often feeling misunderstood and that they have not been listened to (Jonsson \& Svedin, 2012). Studies also indicate that few disclose their experiences of sexual exploitation (Barnert et al., 2017). Could this be due to poor knowledge in society and among caregivers concerning adolescents' experiences of selling sex? Could it be due to stigma or a lack of understanding among healthcare workers? Or could it be due to poor knowledge concerning the motives behind the behaviour? Important factors for disclosing sexual abuse include being believed, being asked, shame/self-blame, concern for oneself and others, and peer influence (McElvaney et al., 2014). These are factors that healthcare workers need to be aware of when meeting adolescents selling sex in a clinical situation, since direct questions need to be asked in relation to the behaviour. Further, the experience of both wanting to tell and not wanting to tell has been described in regard to disclosure (McElvaney et al., 2014). This ambivalence is surely based on the factors described above: concern about not being believed, and shame/self-blame. It is important to highlight this behaviour not only in healthcare but also in society, since adolescents most commonly disclose matters to their peers and family members, and for this reason there is a need within society of a whole to have an understanding of the function of the behaviour. 
Summary and strengths - sex as self-injury

Sex as self-injury is a new field of research and a behaviour in need of conceptualization. To be able to conceptualize a new field of research, different kinds of study methods are needed, and for this thesis both qualitative (Study IV) and quantitative (Study III) studies were used. The self-reported prevalence of SASI on at least one occasion was found to be $2.2 \%(3.2 \%$ among girls and $0.8 \%$ among boys), which has not been investigated in earlier studies. The strength of Studies III and IV was the rather large sample, including 5750 adolescents from the third year of Swedish high school, of which 125 had used SASI on at least one occasion, and the 199 self-selected informants with experience of using SASI, aged 15-64 years, in Study IV. Despite the different study designs and different ages of the participants, the two studies gave similar results; SASI being associated with pain, exposure to physical, emotional and sexual abuse, NSSI, trauma symptoms, depression, anxiety and sexual risk-taking behaviours, such as selling sex and a high number of sexual partners. Even though SASI had often started during adolescence according to Study IV, the same behaviour was described regardless of the age of the participants. This indicates a behaviour that is not new but rather a behaviour that has so far not been highlighted in society.

The participants in the studies reported that they used sex to intentionally injure themselves, associated pain and co-occurrence of NSSI was common. Some informants described altering self-injurious behaviour from NSSI to SASI since it was more invisible. The function of the behaviour was described in the two studies as being comparable to the function of NSSI. In fact, a separate study has been carried out comparing the function of SASI and NSSI for the same sample used in Study III (Jonsson et al., 2017). This study found that the most common functions reported for the two behaviours were automatic functions such as 'To relieve feeling numb or empty', 'To stop bad feelings' or 'To punish oneself'. Social influences such as 'To try to get a reaction from someone, even if it's a negative reaction', 'To get attention' and 'To feel a part of a group' were more commonly reported among adolescents using SASI. The group with the two forms of self-injury (SASI+NSSI) reported more severe forms of NSSI and reported the highest number of functions, indicating a more burdened group (Jonsson et al., 2017). In Study IV, the informants described SASI as deliberate sexual contact that could include physiological or physical harm. The motives were regulation of negative feelings, positive and negative confirmation. Hence, many similarities are seen regarding the function of SASI and direct self-injury, and in the way the behaviours are 
manifested. This indicates that SASI is a behaviour that should be compared to a direct SIB like NSSI, even though it often occurs as an interpersonal act.

Study III and IV highlight the association between SASI and earlier sexual abuse. In an additional study on the same sample used in Study III, risk factors for adolescents using SASI were compared to adolescents using NSSI (Zetterqvist et al., 2018). Adolescents using SASI were found to have more experiences of penetrative sexual abuse and more self-reported trauma symptoms such as dissociation, post-traumatic stress and sexual concerns compared to adolescents using NSSI. No differences were seen between the groups concerning emotional and physical abuse, self-esteem, parental care and overprotection, trauma symptoms of depression, anxiety and anger. In this study, adolescents using both forms of self-injury (SASI + NSSI) were found to be more exposed, including sexual and physical abuse, symptoms of depression, anxiety, dissociation, post-traumatic stress, eating disorders and suicide attempts (Zetterqvist et al., 2018). This is interesting, since earlier studies have been inconclusive in regard to the association between NSSI and sexual abuse (Brown \& Plener, 2017). There are probably several important factors connecting sexual abuse and SASI, such as feeling of shame, self-hatred and hatred of the body, which were described in both Study IV and Study III. In total, $58.6 \%$ of the adolescents in Study III reported using SASI because they did not like their body. In earlier studies of females involved in prostitution, a complicated and distant relationship to the body has been described (Coy, 2009). Some informants in Study IV described that it was better to be in a situation similar to sexual abuse in which the person had some kind of control compared to having the memories from earlier abuse. They described exposing themselves to situations similar to the earlier sexual abuse as a way to cope with memories and flashbacks and this could be compared to the term 'reenactment' (Penning \& Collings, 2014). As seen in the introduction, a theoretical framework for the occurrence of self-injury based on a three factors model (Nock, 2009, 2010) could be seen as following: 1) The function of the self-injury. In regard of SASI this could be regulation of negative feelings or positive or negative confirmation. 2) Factors influencing the affect regulation. In the case of SASI, this could be PTSD increasing anxiety and inducing a negative state of mind. 3) Self-injury specific factors. For SASI, sexual abuse seems to be one of these important factors.

In Study IV, informants described exposing themselves to dangerous and life-threatening situations in SASI. Study III indicated that adolescents using SASI had more risk-taking 
sexual behaviour and had more often been repeatedly exposed to sexual abuse. There are several studies in the literature investigating the association between sexual abuse, sexual risk-taking behaviour and revictimization. The literature is concurrent regarding the findings of child sexual abuse increasing the risk of later sexual revictimization from two to about 14 times (Lalor \& McElvaney, 2010; Messman-Moore \& Long, 2003). Sexual abuse during childhood increases the risk of later sexual risk-taking behaviour including teenage pregnancy, prostitution, early age of first voluntary sexual intercourse, sexually transmitted infections and a high number of sexual partners (Fergusson, Horwood, \& Lynskey, 1997; Lalor \& McElvaney, 2010; Steel \& Herlitz, 2005). Studies indicate that emotional dysregulation is an important factor for sexual risk-taking behaviour, self-injury and revictimization after sexual abuse (Dixon-Gordon et al., 2014; Ford \& Gomez, 2015; Messman-Moore, Walsh, \& DiLillo, 2010; Miron \& Orcutt, 2014; Orcutt et al., 2005; Tull, Weiss, Adams, \& Gratz, 2012). The increased risk of later revictimization could be mediated by sexual self-esteem, sexual concerns and high risk sexual behaviours (Van Bruggen, Runtz, $\&$ Kadlec, 2006) and the use of sex as a way to reduce negative emotions (Lalor \& McElvaney, 2010; Miron \& Orcutt, 2014; Orcutt et al., 2005). This thesis indicates that SASI might be one important risk factor for exposing oneself to sexual situations that could possibly lead to further victimization and traumatization.

\section{Methodological considerations and limitations}

Studies I-III were based on cross-sectional population studies with the aim of investigating selling sex and SASI among Swedish adolescents in a high school sample. According to data from 2014, 91.7\% of all Swedish adolescents aged 18 years were enrolled in the Swedish high school system (Statistics Sweden, 2016). This means that $8 \%$ do not attend school for various reasons. This group could be seen as a risk group for selling sex and SASI, since selling sex among adolescents is associated with feeling unhappy at school and dropping out of school (Brawn \& Roe-Sepowitz, 2008; Kaestle, 2012; McNeal \& Walker, 2016). Further, the response rate was about $60 \%$ for the two surveys. Of the $40 \%$ that did not answer the questionnaire, about $10 \%$ could be calculated as being absent on a regular school day and about $30 \%$ did not agree to participate for different reasons. No investigation was carried out concerning the reasons for not participating in the study, but it can be speculated that adolescents with reading difficulties, attention disabilities or poor knowledge of the Swedish 
language or participants who were feeling distressed due to sensitive questions were those who did not participate in the study. This group might also be a risk group for selling sex or using sex as self-injury. However, the group of adolescents who did not participate in the study is hard to reach in any study using questionnaires. With other study designs for population-based studies, such as sending the questionnaire by mail, the response rate could be expected to be even lower. Response rates as low as $20-30 \%$ have been seen in two large Swedish studies concerning young people and sexual behaviours, which contacted the participants by mail (Folkhälsomyndigheten, 2017; Tikkanen et al., 2011). In conclusion, the study was not fully representative of Swedish adolescents since $8 \%$ of adolescents aged 18 do not attend school and only $60 \%$ participated in the study. This means that the prevalence found in the studies might underestimate the number of adolescents selling sex and using SASI, since adolescents who do not attend school or did not participate could be considered as a risk group.

In Studies II and III, an extra sample for Stockholm County, was included in the studies. This sample was selected according to the same selection criteria as the national sample created by Statistics Sweden. This sample had a lower response rate (48.7\% vs $65.3 \%)$, and more often attended medium-sized schools and vocational study programmes compared to adolescents from the rest of the country. However, the effect size for the differences was small and few differences were found in regard to risk factors and risk behaviours when comparing adolescents from Stockholm County to the rest of the country why it was kept for the studies of this thesis (Stockholm stad, 2017).

In relation to the reliability of the answers, all answers were reviewed for trustworthiness. Five answers were excluded from Study I and 34 answers from Studies II-III due to a high number of missing answers or because the answers were considered untrustworthy. In Study IV, all answers were considered trustworthy. All questions in the studies included selfreported experiences or symptoms, meaning that the credibility of the answers has to be questioned. Answers could be either exaggerated or diminished, and recall bias has to be considered.

Another limitation of the studies was that several questions in the questionnaires were not validated, such as the index question for Study III. This means that we do not know how these questions were interpreted by the informants and whether the answers were reliable. In relation to the index question for SASI in Study III, no question was included regarding how 
SASI had been used. However, this was investigated in Study IV, but the question remains whether SASI would be described in the same way in the national sample compared to the self-selected qualitative sample. Further, the same limitations were seen for other questions such as the questions concerning help and support in Study I. In this study, adolescents selling sex reported being more discontent with the help and support that they had received compared to their peers, but we do not know why or in what way they were discontent.

Another important issue is the power of the statistical calculations. For example, the question concerning gender was formulated for the Studies I-III as: 'Are you...' a) 'male' b) 'female' c) 'This classification does not fit for me'. This classification made it possible to identify adolescents with non-binary gender. This group was very small, and was found to be more vulnerable in several questions such as those concerning sexual abuse. In Study I, calculations were carried out in relation to gender, which was problematic due to the small groups. For the factor analysis in Study II, the KMO value (Kaiser-Meyer-Olkin measure of sampling adequacy) was .59 indicating a low but acceptable sample size. In Study III, boys accounted for relatively small groups and comparisons between the genders indicated that the study was too small to be analysed in terms of gender regarding the responses to several questions.

All of the studies were anonymous questionnaires, which has both limitations and advantages. For Study IV, an anonymous, self-selected, web-based questionnaire was used instead of face-to-face interviews for several reasons. The Internet as a source for finding participants has advantages such as the possibility to recruit informants according to their appropriate fit into the research question rather than their physical location. The sample could be expected to be more diverse, and informants could be expected to express their thoughts more freely compared to face-to-face interviews (Markham, 2011). The disadvantage of anonymous questionnaires compared to face-to-face interviews is the lack of opportunities to ask follow-up questions and the fact that the answers tend to be much shorter. For this reason a fairly large sample was used for Study IV with 199 participants, which could be compared to 15-30 informants as often used in interview studies (Patton, 2015). The length of the answers varied from one sentence to one page. However, the length of the answers did not influence the quality of the answers, which means that one sentence sometimes explained more about the research question than half a page. The large number of informants was a 
strength of the study but also a limitation since the study did not have the possibility to cite all informants, instead showing the bigger picture.

The studies in the thesis mostly used a descriptive approach. The reason for this was the relatively new field of research which concerns both SASI and the selling of sex among adolescents. Study IV included tables detailing the number of informants reporting the main findings, to give the reader a better feeling of the recurrence of patterns and themes. This should not be compared to a mixed method approach. Even though we had a large sample, we did not include direct questions concerning the main findings, meaning that more informants might have had the experience of sexual abuse, experience of violence or physical pain during SASI, but this was not asked directly.

In relation to Study IV, the study was self-selected and the background data for the participants was very limited. This study was not meant to be representative, but was rather designed to investigate the experience of a behaviour (SASI). However, since the study used the websites of NGOs offering help and support to vulnerable women and young people (such as Tjej- and Kvinnojourer), there might have been an overrepresentation of women with the experience of sexual abuse compared to a normally distributed population. On the other hand, these organizations were chosen because of the knowledge from the earlier population-based study that sexual abuse is common among those using SASI, and for this reason informants with experience of SASI were expected to be found via these kinds of websites. However, the strongest limitation of this study was the distribution of gender that did not correspond to the prevalence seen in the national study.

To investigate a behaviour that is yet not conceptualized and accepted in the research field is challenging, since no validated questions are available as mentioned above. However, the questions for the national study might have been more precise and adequate if we had started with a qualitative study and not a quantitative questionnaire. The definition of SASI could also be discussed, since it differed in Studies III and IV. In Study III we included all adolescents who reported having used sex to intentionally hurt themselves on at least one occasion, but in Study IV we used the definition 'repeatedly having sought sexual situations that have resulted in physical and/or mental harm and that have affected the person in his or her life.' 
A further limitation of the studies is the cross-sectional design that cannot provide information about causality, only the associations of risk factors for a behaviour. For example, we know that SASI and selling sex are associated with exposure to sexual abuse as seen in Studies I and III, but we do not know the causality behind this behaviour. However, in regard to sexual abuse, we had the possibility to investigate whether the first instance of sexual abuse had occurred before or after SASI and Study IV was important in terms of understanding how SASI and selling sex were associated with sexual abuse.

\section{Clinical implications}

The current studies highlight the prevalence of adolescents selling sex and the use of SASI. To be able to take a therapeutic approach toward these behaviours, caregivers must first be aware of the existence of the behaviours. By understanding the underlying motives for selling sex and that sexual risk-taking could be a means of self-injury, a different approach can be taken towards the behaviours within healthcare. This affects the kinds of treatments that can be offered, and makes it easier for professionals to identify the behaviour and for patients to seek help.

As seen in Study III, adolescents using SASI had been in contact with healthcare to a high extent for various psychiatric reasons such as suicide attempts, eating disorders and anxiety/depression. However, the question is what treatment do they receive? Are the sexual self-injury behaviour and the earlier experience of sexual abuse even addressed? The findings are in line with earlier research showing that a large number of victims of child sexual exploitation are often in contact with healthcare for complaints such as psychiatric issues, pain, injuries, gynaecological problems and sexual assaults (Greenbaum, 2018). Yet, as seen in Study I and earlier studies, adolescents selling sex often feel misunderstood and not listened to when seeking help and support (Jonsson \& Svedin, 2012). Even though contact with healthcare is common for this group, few disclose their experience of sexual exploitation (Barnert et al., 2017). Disclosing sexual exploitation or sexual abuse could be difficult, since it is often associated with shame and self-blame (Ijadi-Maghsoodi et al., 2018; McElvaney et al., 2014). Disclosing experiences of SASI or selling sex might be even more difficult since the person has been active in seeking the situation and might even have been raped or abused as a consequence. These patients do not seek out healthcare for SASI or selling sex. Instead, 
they will seek healthcare with symptoms of poor mental health including anxiety/depression, suicidal thoughts or suicide attempts, drug abuse, sleeping problems, NSSI, eating disorders, stomach pain or headache. Healthcare needs to acknowledge the behaviour and ask about SASI, sexual abuse and selling sex in order to be able to give proper help and support and not only treat the symptoms of the behaviour. Caregivers need to ask about these behaviours, especially in professions that meet these patients often such as institutions, psychiatric wards, abortion clinics, clinics for sexually transmitted infections (STIs) and clinics for addiction, as well as emergency departments and primary care.

The studies in this thesis indicate that SASI could be compared to NSSI and the two behaviours could be intertwined with each other. This means that asking questions concerning SASI when treating other kinds of SIB is important, since they could coexist and replace one and another. Some informants said that they had stopped cutting themselves but continued with SASI because it was more invisible, satisfying those around them, but they had simply replaced one destructive behaviour with another. Hence, it is important to treat not only one SIB but all SIBs concurrently.

Suicidal behaviour was found to be connected to SASI in that about $30 \%$ sought healthcare for attempted suicide according to Study III. In Study IV, risk-taking situations were recurrently described including strangling, fear of kidnapping or even fear of being killed. Assessing the risk of further revictimization, exposure to dangerous or life-threatening situations and the risk of suicide is important when dealing with patients selling sex or patients using SASI to prevent further victimization.

In regard to treatment, adolescents using SASI are in need of a therapeutic approach where they receive support and psychoeducation concerning affect regulation as well as trauma treatment. The most evidenced based PTSD treatments in Sweden today are psychological exposure therapies such as Cognitive behavioural therapy (CBT) and Eye moment desensitization and reprocessing (EMDR) (Bidö, Mannheimer, \& Samuelberg, 2018). The most common treatments for self-injury are currently dialectal behaviour therapy (DBT), cognitive behaviour therapy for suicide prevention and mentalization-based treatment (Ford \& Gomez, 2015). Studies indicate that patients with borderline personality disorder and PTSD have a greater reduction in suicide attempts and self-injury when DBT is combined with trauma treatment (Ford \& Gomez, 2015; Harned, Gallop, \& Valenstein-Mah, 2018; Harned, Korslund, \& Linehan, 2014). Emotion regulation group therapy (ERGT) is another 
acceptable method used in Sweden today for self-injurious behaviour (Sahlin et al., 2017). As seen in study III complex symptoms are common among adolescents using SASI indicating the need to work in a team with these patients. Further, dissociation could be induced by reminders of the trauma. Dissociation could hamper the exposure to trauma memories in treatment and is a further reason to use learning strategies for affect regulation in trauma treatment (Schauer \& Elbert, 2010).

In regard to help and support for adolescents selling sex, it is important to ask questions about motives for selling sex since adolescent are a heterogeneous group in regard of underlying motives. Some use the behaviour as a means of self-injury, which is why the self-injurious part also has to be addressed in treatment. Some use selling sex as a way to receive money or to support drug addiction, and for these individuals it is important to investigate the social and economic situation and the occurrence of drug addiction. Some informants sold sexual services for pleasure and fun, possibly more as a way of sexual exploration, and this group might not need any help and support from healthcare in regard to the selling of sex. However, this group still had high levels of trauma symptoms and was more exposed to e.g. sexual abuse compared to the general population, which is why other problems possibly need to be addressed for this group.

Sexual abuse is a recurrent pattern for both adolescents selling sex and individuals using SASI. The self-reported prevalence of sexual abuse in the third year of Swedish high school is one in five, and of the girls one in ten have been exposed to penetrative sexual abuse (Svedin et al., 2015). Asking questions about exposure to sexual abuse is crucial for preventive work in connection with SASI and selling sex. These issues need to be addressed not only in healthcare but also in schools. Sexual abuse can take many forms which young people and other sections of society might not be aware of, and might have the traditional view of the perpetrator being an unknown person and the assault happening in a park or on the street. On the contrary, according to these studies, 37.4\% had a perpetrator who was unknown but $23 \%$ were subjected to abuse by a peer that the person knew, $13.1 \%$ by a boyfriend or girlfriend, and $7.5 \%$ by someone that they knew from the Internet (Svedin et al., 2015). Exposure to sexual abuse on the Internet is another important issue to highlight in society today (Landberg \& Jonsson, 2017). Knowledge concerning sexual abuse is important for adolescents not only to prevent shame and self-blame but also because friends and peers are the first people that abused adolescents confide in as seen in this thesis. Preventive work 
concerning sexual abuse is also important to reduce the occurrence of SASI and adolescents selling sex. A further risk group for SASI and selling sex are people with non-heterosexual orientation (Boyer et al., 2017; Svedin \& Priebe, 2004, 2009; Tikkanen et al., 2011). Particular attention should be paid to this group in connection with preventive work concerning SASI and selling sex.

\section{Future directions}

First, SASI is a new field of research, which is why the findings in this thesis need to be confirmed in future studies. The studies in this thesis are all based on Swedish samples, and it would be interesting to investigate whether they could be framed in other parts of the world. Do people in other cultures also identify sexual destructive behaviours with SIB? What underlying motives for selling sex could be seen in other parts of the world in a national population?

In regard to motives for selling sex, Study II is the first population-based study to investigate motives for selling sex and attempt to identify groups of adolescents according to underlying motives. The small sample size is a limitation, and these results therefore need to be repeated in order to confirm the findings for a Swedish population.

A further interesting field is to look into the longitudinal effects of SASI and selling sex. What effects does it have on the healthcare burden? Are there economic disadvantages from a longer-term perspective, e.g. lost income for mental health effects? What social influences does it have? What effects does it have in regard to sexual relationships?

As has been suggested by American Psychiatric Association, NSSI is a concept in need of more research (American Psychiatric Association, 2013). Further research is needed to evaluate whether SASI could be part of the NSSI diagnosis or whether it should be seen as a separate behaviour. According to this thesis, there are aspects of this behaviour that could clearly be viewed as a direct SIB, but there are also descriptions of SASI that might be viewed more as a sexual risk-taking behaviour or indirect SIB. Further, the association between complex PTSD and borderline personal disorder has not yet been investigated. It is possible that SASI imbricates closely with these two diagnoses, which could affect clinical aspects especially in relation to treatment. 
Motives for and manifestations of SASI were identified in Study IV, and many findings were comparable with the findings from the epidemiological studies (Fredlund et al., 2017; Jonsson et al., 2017; Zetterqvist et al., 2018). Sexual abuse was a recurrent risk factor in this thesis for both selling sex and SASI. In Study IV, SASI was described as a way to take control of the memories of sexual abuse, to repeat the experiences of abuse or to punish oneself because of self-hatred to the body after sexual abuse. Further studies is needed to investigate the association between SASI and sexual abuse. It would be interesting to investigate if SASI is manifested in the same way for people with and without experiences of sexual abuse.

SASI and selling sex are behaviours that need to be highlighted in healthcare, especially on psychiatric wards where proper help and support need to be developed. There are currently no evaluated treatment programmes for people who use SASI. They might be included in the treatment programmes offered by clinics for other kinds of self-injury, but these have not been evaluated for SASI. One important step forward in the work concerning SASI and adolescents selling sex is to look into factors that are important to stop using SASI. What are the experiences in regard to help and support when using SASI? What has been helpful in earlier contact with healthcare? How could healthcare be better at preventing SASI and preventing adolescents from selling sex? It is important to look into these factors from the perspective of the patients before interventions are implemented in clinical contexts. Further, to be able to give proper help and support in psychiatric care, it would be helpful to investigate the prevalence of SASI and the occurrence of people selling sex in a psychiatric population. 


\section{Conclusions}

In conclusion, selling sex and SASI are sexual behaviours that need to be highlighted in healthcare and society, since these behaviours are closely associated with experiences of adverse events, poor mental health and trauma symptoms. This thesis is a first attempt to frame the concept of SASI which according to this thesis is a behaviour that could be compared to directly self-injurious behaviour. SASI is a behaviour in need of further research, especially in other kinds of cultures and societies, in order to be further conceptualized. Understanding adolescents' motives for selling sex is an important step to be able to offer proper help and support to the group. Emotional, material and pleasure-related factors are the most important underlying motives for adolescents to sell sex in Sweden, but further research is needed to determine whether the same motives could be seen in countries with lower socioeconomic conditions or different cultural aspects. In regard to help and support for adolescents selling sex and SASI, it is clear that this group comes into contact with healthcare in concern of other problems such as anxiety/depression, eating disorders and suicide attempts. There is currently no validated treatment for adolescents selling sex or using SASI, but according to the findings in this thesis this group might need both trauma treatment and therapy for affect regulation. For some persons selling sex or using SASI alcohol or drug addiction needs to be addressed. Further, assessing the risk of victimization and suicide assessment is important in the consultation with these patients. 


\section{Sammanfattning på Svenska}

Det finns idag endast ett fåtal befolkningsstudier som undersöker förekomsten av unga som säljer sex och associerade riskfaktorer och ingen tidigare befolkningsstudier har undersökt bakomliggande orsaker till att unga säljer sex. Sex som självskada har uppmärksammats i Sverige de senaste åren men detta är ett nytt forskningsområde där det idag saknas en vedertagen definition.

Avhandlingens syfte var att undersöka förekomsten, associerade riskfaktorer och bakomliggande orsaker till att unga säljer sex samt har sex som självskada i Sverige. Vidare undersöktes hur sex som självskada (SASI) kan ta sig uttryck. Avhandlingen inkluderade två nationella studier med 3498 respektive 5829 ungdomar från tredje året på svenska gymnasiet, medelålder 18 år. Sex som självskada undersöktes även i en kvalitativ studie med 199 deltagare i åldern 15-64 år, medelålder 27.9 år.

Totalt uppgav $1.5 \%$ av gymnasieeleverna, $1.7 \%$ av pojkarna och $1.2 \%$ av flickorna, att de någon gång hade sålt sex. Att sälja sex var kopplat till sexuella, psykiska och fysiska övergrepp, dåligt psykiskt mående och självskadebeteende. Studie II visade på tre huvudsakliga bakomliggande orsaker till varför unga säljer sex i Sverige; känslomässiga orsaker, materiella orsaker samt lust. Beroende på bakomliggande orsaker till varför man sålde sex skiljde sig grupperna åt vad gäller typ av ersättning, ålder på köparen, kontaktsätt med köparen, sexuell orientering, utsatthet för sexuella övergrepp och erfarenhet av SASI. Studie III visade att $3.2 \%$ av flickorna och $0.8 \%$ av pojkarna på tredje året på gymnasiet hade erfarenhet av SASI. Som grupp var dessa personer mer utsatta för sexuella, fysiska och psykiska övergrepp. Traumasymptom, självskada och icke-heterosexuell läggning var vanligt i gruppen och stor del hade sökt sjukvård för depression/ångest, suicidförsök och ätstörningsproblematik. I studie IV beskrevs SASI som en avsiktlig sexuell kontakt som kan inkludera psykisk och fysisk skada. SASI var ett sätt att hantera dåligt psykiskt mående så som ångest eller tidigare sexuella övergrepp. Det var också ett sätt att få positiv eller negative 
bekräftelse. Beteendet kunde vara svårt att bryta och det kunde leda till en ond spiral med mer och mer destruktiva och farliga sexuella situationer.

Sammanfattningsvis beskrivs SASI vara jämförbart med direkt självskadebeteende så som att skära eller bränna sig. Att sälja sex kan vara en del av SASI men att sälja sex kan också fylla andra funktioner bland svenska ungdomar. Både att sälja sex och SASI är associerat med tidigare utsatthet och dåligt psykiskt mående och bör där med uppmärksammas inom sjukvården och i samhället för att förhindra vidare skador och traumatisering. 


\section{Acknowledgments in Swedish}

Stort tack till mina handledare Marie Wadsby och Carl Göran Svedin för ert engagemang och er stöttning under mitt arbete som doktorand. Tack Carl Göran för din inspiration som har lett mig fram till att börja och fortsätta med forskningen. Till inspirerande möten som leder tankarna vidare. Tack Marie för att du alltid är på plats, tillgänglig och alltid ger mig snabba svar på mina frågor. Du har varit en viktig stöttning under dessa år. Jag är tacksam för att ha fått ha er båda som handledare under mitt arbete då ni kompletterar varandra väl.

Tack Linda Jonsson för ditt engagemang, du har varit en viktig mentor och handledare för mig under hela arbetet (även om du inte varit det på pappret). Din tidigare forskning har varit viktigt för denna avhandling för att inte tala om din hjälp i utformning av studierna, särskilt Studie IV.

Gisela Priebe, tack för att jag fick jobba tillsammans med dig med Studie II. Dina kommentarer och tankar har fått mig att lyfta kunskapsmässigt och att tänka i nya banor vad gäller metoder och analyser.

Tack Örjan Dahlström för hjälp med statistiska frågor inte bara för studie II utan även diskussioner som uppkommit i relation till studie III. Tack till Rikard Tordön och Laura Korhonen för era kommentarer till kappan. Tack Paul Brook för hjälp med språkgranskning i de första studierna.

Tack till min familj, mina vänner och inte minst min sambo David Ekqvist för stöttning under dessa år. Ett extra stort tack till mina barn Noomi och Emanuel för den glädje och värme som ni sprider, för att ni alltid finns med mig och för att ni får mig att förstå hur mycket viktigare saker det finns i livet än arbete, avhandling och karriär.

Till sist vill jag tacka alla informanter som har varit med och delat sina berättelser. Tack till Malin Meissner och Malin Jenstav på Stockholms tjejjour för er hjälp i Studie IV och alla övriga organisationer som hjälpte till att bidra till denna studie; Stockholms Tjejjour, Ungdomsjouren Animo, Örebro tjejjour, Tjejjouren Luleå, Tjejjouren Lund, Tjejjouren Norrköping, Tjejjouren Beate Linköping, Tjejjouren Miranda, Tjejjouren Lina, Lycksele 
Tjejjour, Tjejjouren Indra, Juventas Ungdomsjour, Uppsala Tjejjour, Trans- och Tjejjouren Malmö, Karlstad Tjejjour, Tjejjouren Lotus, Tjejjouren Meja, Tjejjouren Magnolia, Tjejjouren Ronja, Föreningen Storasystrar, Föreningen Tillsammans, RFSU, Tjejzonen, RISE, HOPP, WONSA, 1000 möjligheter, Sheedo, Föreningen Tilia, Roks, Unizon, tjejjouren.se, inte till salu, Kvinno- och tjejjouren Huddinge, Kristianstad kvinnojour, kvinnohuset $\mathrm{KG}$ and umo.se 


\section{References}

Abelsson, J., \& Hulusjö, A. (2008). I sexualitetens gränstrakter - en studie av ungdomar i Göteborg med omnejd som säljer och byter sexualla tjänster. Göteborg, Sweden: Göteborg stad Sociala resursförvaltningen.

Ahlgren, T., Näslund, J., \& Roslander, M. (2009). Ungdomars attityder och erfarenheter när det gäller att köpa och sälja sex. Jönköping, Sweden: Luppen kunskapscentrum.

Aho, N., Gren-Landell, M., \& Svedin, C. G. (2016). The Prevalence of Potentially Victimizing Events, Poly-Victimization, and Its Association to Sociodemographic Factors: A Swedish Youth Survey. Journal of Interpersonal Violence, 31(4), 620-651. doi:10.1177/0886260514556105

Alisic, E., Zalta, A. K., Van Wesel, F., Larsen, S. E., Hafstad, G. S., Hassanpour, K., \& Smid, G. E. (2014). Rates of post-traumatic stress disorder in trauma-exposed children and adolescents: Meta-analysis. British Journal of Psychiatry, 204(5), 335-340. doi:10.1192/bjp.bp.113.131227

American Psychiatric Association. (2013). Diagnostic and statistical manual of mental disorders 5th ed. : DSM-5 (5 ed.). Arlington, Va.: American Psychiatric Association.

Andover, M. S., Holman, C. S., \& Shashoua, M. Y. (2014). Functional assessment of non-suicidal self-injury and eating disorders. In Non-Suicidal Self-Injury in Eating Disorders: Advancements in Etiology and Treatment (Vol. 9783642401077, pp. 87-104).

Arata, C. M. (2000). From child victim to adult victim: a model for predicting sexual revictimization. Child Maltreatment, 5(1), 28-38. doi:10.1177/1077559500005001004

Artologik. Retrieved from https://www.artologik.com/en/Start.aspx 2 December 2018

Attanayake, V., McKay, R., Joffres, M., Singh, S., Burkle Jr, F., \& Mills, E. (2009). Prevalence of mental disorders among children exposed to war: a systematic review of 7,920 children.

Medicine, conflict, and survival, 25(1), 4-19. doi:10.1080/13623690802568913

Bagley, C., \& Young, L. (1987). Juvenile prostitution and child sexual abuse: A controlled study. Canadian Journal of Community Mental Health, 6(1), 5-26. doi:10.7870/cjcmh-1987-0001

Ballard, E., Bosk, A., \& Pao, M. (2010). Invited commentary: understanding brain mechanisms of pain processing in adolescents' non-suicidal self-injury. Journal of Youth Adolescence, 39(4), 327-334. doi:10.1007/s10964-009-9457-1 
Barnert, E., Iqbal, Z., Bruce, J., Anoshiravani, A., Kolhatkar, G., \& Greenbaum, J. (2017).

Commercial Sexual Exploitation and Sex Trafficking of Children and Adolescents: A Narrative Review. Acada Pediatrica, 17(8), 825-829. doi:10.1016/j.acap.2017.07.009

Batejan, K. L., Jarvi, S. M., \& Swenson, L. P. (2015). Sexual Orientation and Non-Suicidal SelfInjury: A Meta-Analytic Review. Archives of Suicide Research, 19(2), 131-150. doi:10.1080/13811118.2014.957450

Bidö, S., Mannheimer, M., \& Samuelberg, P. (2018). Traumatisering hos barn : en handbok: [Stockholm] : Natur \& Kultur , [2018]

Första utgåvan.

Blades, C. A., Stritzke, W. G. K., Page, A. C., \& Brown, J. D. (2018). The benefits and risks of asking research participants about suicide: A meta-analysis of the impact of exposure to suicide-related content. Clinical Psychology Review, 64, 1-12. doi:10.1016/j.cpr.2018.07.001

Boyer, C. B., Greenberg, L., Chutuape, K., Walker, B., Monte, D., Kirk, J., . . Munoz, M. (2017). Exchange of Sex for Drugs or Money in Adolescents and Young Adults: An Examination of Sociodemographic Factors, HIV-Related Risk, and Community Context. Journal of Community Health, 42(1), 90-100. doi:10.1007/s10900-016-0234-2

Brausch, A. M., \& Muehlenkamp, J. J. (2014). Experience of the body. In Non-Suicidal Self-Injury in Eating Disorders: Advancements in Etiology and Treatment (pp. 237-253).

Brawn, K. M., \& Roe-Sepowitz, D. (2008). Female juvenile prostitutes: Exploring the relationship to substance use. Children and Youth Services Review, 30(12), 1395-1402. doi:10.1016/j.childyouth.2008.04.011

Bresin, K., \& Gordon, K. H. (2013a). Changes in negative affect following pain (vs. nonpainful) stimulation in individuals with and without a history of nonsuicidal self-injury. Personal Disord, 4(1), 62-66. doi:10.1037/a0025736

Bresin, K., \& Gordon, K. H. (2013b). Endogenous opioids and nonsuicidal self-injury: a mechanism of affect regulation. Neuroscience \& Biobehavioral Reviews, 37(3), 374-383. doi:10.1016/j.neubiorev.2013.01.020

Bresin, K., \& Schoenleber, M. (2015). Gender differences in the prevalence of nonsuicidal self-injury: A meta-analysis. Clinical Psychology Review, 38, 55-64. doi:10.1016/j.cpr.2015.02.009

Brewin, C. R., Cloitre, M., Hyland, P., Shevlin, M., Maercker, A., Bryant, R. A., . . Reed, G. M. (2017). A review of current evidence regarding the ICD-11 proposals for diagnosing PTSD and complex PTSD. Clinical Psychology Review, 58, 1-15. doi:https://doi.org/10.1016/j.cpr.2017.09.001

Briere, J. (1996). Trauma symptom checklist for children (TSCC) professional manual. Odessa: Psychological Assessment Reource. 
Brown, R. C., \& Plener, P. L. (2017). Non-suicidal Self-Injury in Adolescence. Current Psychiatry Reports, 19(3). doi:10.1007/s11920-017-0767-9

Brunner, R., Kaess, M., Parzer, P., Fischer, G., Carli, V., Hoven, C. W., . . Wasserman, D. (2014). Life-time prevalence and psychosocial correlates of adolescent direct self-injurious behavior: A comparative study of findings in 11 European countries. Journal of Child Psychology and Psychiatry and Allied Disciplines, 55(4), 337-348. doi:10.1111/jcpp.12166

Butler, J. A. (2016). Self-harm. Medicine (United Kingdom), 44(12), 715-719. doi:10.1016/j.mpmed.2016.09.003

Carlsson, J. (2012). Sex som självskadebeteende: fenomenet ur terapeuters perspektiv. Lund, Sweden: Lund University, Insitution of psychology

Claes, L., \& Muehlenkamp, J. J. (2014). Non-suicidal self-injury and eating disorders: Dimensions of self-harm. In Non-Suicidal Self-Injury in Eating Disorders: Advancements in Etiology and Treatment (Vol. 9783642401077 , pp. 3-18).

Claes, L., \& Vandereycken, W. (2007). Self-injurious behavior: differential diagnosis and functional differentiation. Comprehensive Psychiatry, 48(2), 137-144. doi:10.1016/j.comppsych.2006.10.009

Clarke, R. J., Clarke, E. A., Roe-Sepowitz, D., \& Fey, R. (2012). Age at Entry into Prostitution: Relationship to Drug Use, Race, Suicide, Education Level, Childhood Abuse, and Family Experiences. Journal of Human Behavior in the Social Environment, 22(3), 270-289. doi:10.1080/10911359.2012.655583

Cook, A., Spinazzola, J., Ford, J., Lanktree, C., Blaustein, M., Cloitre, M., . . Van Der Kolk, B. (2005). Complex trauma in children and adolescents. Psychiatric Annals, 35(5), 390-398. doi:10.3928/00485713-20050501-05

Coy, M. (2009). This body which is not mine: The notion of the habit body, prostitution and (dis)embodiment. Feminist Theory, 10(1), 61-75. doi:10.1177/1464700108100392

Cullen, K. R., Westlund, M. K., LaRiviere, L. L., \& Klimes-Dougan, B. (2013). An adolescent with nonsuicidal self-injury: A case and discussion of neurobiological research on emotion regulation. American Journal of Psychiatry, 170(8), 828-831. doi:10.1176/appi.ajp.2013.12121598

Dahlström, O., Zetterqvist, M., Lundh, L. G., \& Svedin, C. G. (2015). Functions of nonsuicidal selfinjury: Exploratory and confirmatory factor analyses in a large community sample of adolescents. Psychological Assessment, 27(1), 302-313. doi:10.1037/pas0000034

Davidson, I., \& Runegrund, R. (1999). Den Svenska handlingplanen mot kommersiell sexuall exploatering av barn. Stockholm: Socialutskottet.

Deeley, S. T., \& Love, A. W. (2010). Does asking adolescents about suicidal ideation induce negative mood state? Violence and Victims, 25(5), 677-688. doi:10.1891/0886-6708.25.5.677 
Derogatis, L. R. (1983). SCL-90-R, Administration, Scoring and Procedures Manual (Manual. 2nd ed.). Baltimore, MD.: Procedures Psychometric Research.

Dixon-Gordon, K. L., Tull, M. T., \& Gratz, K. L. (2014). Self-injurious behaviors in posttraumatic stress disorder: an examination of potential moderators. Journal of Affective Disorders, 166, 359-367. doi:10.1016/j.jad.2014.05.033

Dunlap, E., Golub, A., \& Johnson, B. D. (2004). Girls' Sexual Development in the Inner City: From Compelled Childhood Sexual Contact to Sex-for-Things Exchanges. Journal of Child Sexual Abuse, 12(2), 73-96. doi:10.1300/J070v12n02_04

Edinburgh, L., Pape-Blabolil, J., Harpin, S. B., \& Saewyc, E. (2015). Assessing exploitation experiences of girls and boys seen at a Child Advocacy Center. Child Abuse \& Neglect, 46, 4759. doi:10.1016/j.chiabu.2015.04.016

Edwards, J. M., Iritani, B. J., \& Hallfors, D. D. (2006). Prevalence and correlates of exchanging sex for drugs or money among adolescents in the United States. Sexually Transmitted Infections, 82(5), 354-358. doi:10.1136/sti.2006.020693

Eisenberger, N. I. (2012). The neural bases of social pain: evidence for shared representations with physical pain. Psychosomatic Medicine, 74(2), 126-135. doi:10.1097/PSY.0b013e3182464dd1

Engvall, C. (2008). 14 år till salu : en sann svensk historia. Stockholm: Kalla kulor förlag.

Engvall, C. (2011). Skamfläck : svenska barns verkliga helvete. Stockholm: Kalla kulor förlag.

Esposito, C., Spirito, A., Boergers, J., \& Donaldson, D. (2003). Affective, Behavioral, and Cognitive Functioning in Adolescents with Multiple Suicide Attempts. Suicide and Life-Threatening Behavior, 33(4), 389-399. doi:10.1521/suli.33.4.389.25231

Farley, M. (2003). Prostitution and the invisibility of harm. Women and Therapy, 26(3-4), 247-280. doi:10.1300/J015v26n03_06

Fergusson, D. M., Horwood, L. J., \& Lynskey, M. T. (1997). Childhood sexual abuse, adolescent sexual behaviors and sexual revictimization. Child Abuse \& Neglect, 21(8), 789-803. doi:10.1016/S0145-2134(97)00039-2

Folkhälsomyndigheten. (2017). Sexualitet och hälsa bland unga i Sverige. UngKAB15 - en studie om kunskap attityder och beteendebland unga 16-29 år: Folkhälsomyndigheten.

Ford, J. D., \& Gomez, J. M. (2015). The relationship of psychological trauma and dissociative and posttraumatic stress disorders to nonsuicidal self-injury and suicidality: a review. Journal of Trauma \& Dissociation, 16(3), 232-271. doi:10.1080/15299732.2015.989563

Fredlund, C., Svedin, C. G., Priebe, G., Jonsson, L., \& Wadsby, M. (2017). Self-reported frequency of sex as self-injury (SASI) in a national study of Swedish adolescents and association to sociodemographic factors, sexual behaviors, abuse and mental health. Child and Adolescent Psychiatry and Mental Health, 11(1). doi:10.1186/s13034-017-0146-7 
Fredlund, C., Svensson, F., Svedin, C. G., Priebe, G., \& Wadsby, M. (2013). Adolescents' lifetime experience of selling sex: Development over five years. Journal of Child Sexual Abuse, 22(3), 312-325. doi:10.1080/10538712.2013.743950

Gibbs Van Brunschot, E., \& Brannigan, A. (2002). Childhood maltreatment and subsequent conduct disorders - The case of female street prostitution. International Journal of Law and Psychiatry, 25(3), 219-234. doi:10.1016/S0160-2527(02)00103-6

Gimstam-Jarl, S., \& Thögersen, J. (2012). Att skada sig med sex - En kvalitativ studie om professionallas syn på och arbeta med unga som har ett destruktivt sexuellt beteende. Stockholm, Sweden: Stockholm University institution for Social work.

Greenbaum, J. (2018). Child Sex Trafficking and Commercial Sexual Exploitation. Advances in Pediatrics, 65, 55-70. doi:10.1016/j.yapd.2018.04.003

Greene, J. M., Ennett, S. T., \& Ringwalt, C. L. (1999). Prevalence and correlates of survival sex among runaway and homeless youth. American Journal of Public Health, 89(9), 1406-1409. doi:10.2105/AJPH.89.9.1406

Haines, J., Williams, C. L., Brain, K. L., \& Wilson, G. V. (1995). The Psychophysiology of SelfMutilation. Journal of Abnormal Psychology, 104(3), 471-489. doi:10.1037/0021843X.104.3.471

Hallett, S. (2017). Making sense of child sexual exploitation : exchange, abuse and young people. Bristol Policy Press.

Hamza, C. A., Stewart, S. L., \& Willoughby, T. (2012). Examining the link between nonsuicidal selfinjury and suicidal behavior: A review of the literature and an integrated model. Clinical Psychology Review, 32(6), 482-495. doi:10.1016/j.cpr.2012.05.003

Harned, M. S., Gallop, R. J., \& Valenstein-Mah, H. R. (2018). What changes when? The course of improvement during a stage-based treatment for suicidal and self-injuring women with borderline personality disorder and PTSD. Psychotherapy Research, 28(5), 761-775. doi:10.1080/10503307.2016.1252865

Harned, M. S., Korslund, K. E., \& Linehan, M. M. (2014). A pilot randomized controlled trial of Dialectical Behavior Therapy with and without the Dialectical Behavior Therapy Prolonged Exposure protocol for suicidal and self-injuring women with borderline personality disorder and PTSD. Behaviour Research and Therapy, 55(1), 7-17. doi:10.1016/j.brat.2014.01.008

Heilemann, T., \& Santhiveeran, J. (2011). How do female adolescents cope and survive the hardships of prostitution? A content analysis of existing literature. Journal of Ethnic and Cultural Diversity in Social Work, 20(1), 57-76. doi:10.1080/15313204.2011.545945

Hershberger, A. R., Sanders, J., Chick, C., Jessup, M., Hanlin, H., \& Cyders, M. A. (2018). Predicting running away in girls who are victims of commercial sexual exploitation. Child Abuse \& Neglect, 79, 269-278. doi:https://doi.org/10.1016/j.chiabu.2018.02.023 
Houck, C. D., Hadley, W., Lescano, C. M., Pugatch, D., \& Brown, L. K. (2008). Suicide attempt and sexual risk behavior: Relationship among adolescents. Archives of Suicide Research, 12(1), 3949. doi:10.1080/13811110701800715

Hwang, S. L., \& Bedford, O. (2003). Precursors and pathways to adolescent prostitution in Taiwan. Journal of Sex Research, 40(2), 201-210. doi:10.1080/00224490309552181

Hwang, S. L., \& Bedford, O. (2004). Juveniles' motivations for remaining in prostitution. Psychology of Women Quarterly, 28(2), 136-146. doi:10.1111/j.1471-6402.2004.00130.x

Ijadi-Maghsoodi, R., Bath, E., Cook, M., Textor, L., \& Barnert, E. (2018). Commercially sexually exploited youths' health care experiences, barriers, and recommendations: A qualitative analysis. Child Abuse \& Neglect, 76, 334-341. doi:10.1016/j.chiabu.2017.11.002

International Society for the Study of Self-Injury [ISSS]. (2018). About self-injury. Retrieved 2018 November 22 from https://itriples.org/category/about-self-injury/.

Jenstav, M., \& Meissner, M. (2016). "Jag önskar att jag vågat prata med någon" om att få stöd och hjälp ur ett sexuellt självskadebeteende. Stockholm, Sweden: Stockholms Tjejjour.

Jonsson, L., \& Lundström Mattsson, Å. (2012). Unga som skadar sig genom sex. Stockholm: Stiftelsen Allmänna barnhuset.

Jonsson, L., \& Svedin, C. (2012). "Online är jag någon annan ... " Unga kvinnor med erfarenhet av att sälja sexuella tjänster online. Delrapport 8 ur Prostitution i Sverige - Kartläggning och utvärdering av prostitutionsgruppernas insatser samt erfarenheter och attityder i befolkningen: Linköping : Linköping University Electronic Press, 2012.

Jonsson, L. S., Svedin, C. G., \& Hyden, M. (2014). "Without the internet, i never would have sold sex": Young women selling sex online. Cyberpsychology, 8(1). doi:10.5817/CP2014-1-4

Jonsson, L. S., Svedin, C. G., \& Hydén, M. (2015). Young women selling sex online narratives on regulating feelings. Adolescents Health and Therapeutics, 6, 1-11. doi:10.2147/AHMT.S77324

Jonsson, L. S., Svedin, C. G., Priebe, G., Fredlund, C., Wadsby, M., \& Zetterqvist, M. (2017). Similarities and Differences in the Functions of Nonsuicidal Self-Injury (NSSI) and Sex as Self-Injury (SASI). Suicide and Life-Threatening Behavior. doi:10.1111/sltb.12417

Kaess, M., Hille, M., Parzer, P., Maser-Gluth, C., Resch, F., \& Brunner, R. (2012). Alterations in the neuroendocrinological stress response to acute psychosocial stress in adolescents engaging in nonsuicidal self-injury. Psychoneuroendocrinology, 37(1), 157-161. doi:10.1016/j.psyneuen.2011.05.009

Kaestle, C. E. (2012). Selling and buying sex: a longitudinal study of risk and protective factors in adolescence. Prevevention Science, 13(3), 314-322. doi:10.1007/s11121-011-0268-8

Karlsson, G., Lönnbohm, A., \& Söderberg, K. (2013). Sex as self-harm - a paper on professional's understunding of the phenomenon. Retrieved from Umeå University 
Kennedy, M. A., Klein, C., Bristowe, J. T. K., Cooper, B. S., \& Yuille, J. C. (2007). Routes of recruitment: Pimps' techniques and other circumstances that lead to street prostitution. Journal of Aggression, Maltreatment and Trauma, 15(2), 1-19. doi:10.1300/J146v15n02_01

Kessler, R. C., Aguilar-Gaxiola, S., Alonso, J., Benjet, C., Bromet, E. J., Cardoso, G., . . On behalf of the, W. H. O. W. M. H. S. C. (2017). Trauma and PTSD in the WHO World Mental Health Surveys. European Journal of Psychotraumatology, 8. doi:10.1080/20008198.2017.1353383

Klonsky, E. D. (2007a). The functions of deliberate self-injury: a review of the evidence. Clinical Psychology Review, 27(2), 226-239. doi:10.1016/j.cpr.2006.08.002

Klonsky, E. D. (2007b). Non-suicidal self-injury: an introduction. Journal of Clinical Psychology, 63(11), 1039-1043. doi:10.1002/jclp.20411

Klonsky, E. D., Glenn, C. R., Styer, D. M., Olino, T. M., \& Washburn, J. J. (2015). The functions of nonsuicidal self-injury: Converging evidence for a two-factor structure. Child and Adolescent Psychiatry and Mental Health, 9(1). doi:10.1186/s13034-015-0073-4

Kotrla, K. (2010). Domestic minor sex trafficking in the United States. Social Work, 55(2), 181-187. doi:10.1093/sw/55.2.181

Kuosmanen, J. (2008). Tio år med lagen. Om förhållningssätt till och erfarenheter av prostitution i Sverige. In C. Holmström \& M.-L. Skilbrei (Eds.), Prostitutionen i Norden. Forskningsrapport (pp. 357-381). Köpenhamn: Nordiska ministerrådet.

Lalor, K., \& McElvaney, R. (2010). Child Sexual Abuse, Links to Later Sexual Exploitation/HighRisk Sexual Behavior, and Prevention/Treatment Programs. Trauma, Violence, and Abuse, 11(4), 159-177. doi:10.1177/1524838010378299

Landberg, Å., \& Jonsson, L. S. (2017). En del av verkligheten - om barn, sexuella övergrepp och nätet: Stiftelsen Allmänna Barnahuset.

Lavoie, F., Thibodeau, C., Gagné, M. H., \& Hébert, M. (2010). Buying and selling sex in Québec adolescents: A study of risk and protective factors. Archives of Sexual Behavior, 39(5), 11471160. doi:10.1007/s10508-010-9605-4

Lee, T. Y., Shek, D. T. L., \& Busiol, D. (2016). A Longitudinal Study of Compensated Dating and Juvenile Prostitution Behaviors Among Adolescents in Hong Kong. Journal of Pediatric and Adolescent Gynecology, 29(1), S31-S37. doi:10.1016/j.jpag.2015.10.006

Littleton, H. L., Grills-Taquechel, A. E., Buck, K. S., Rosman, L., \& Dodd, J. C. (2013). Health Risk Behavior and Sexual Assault Among Ethnically Diverse Women. Psychology of Women Quarterly, 37(1), 7-21. doi:10.1177/0361684312451842

Lloyed, E. E., Kelley, M. L., \& Hope, T. (1997). Self-mutilation in a community sample of adolescents. Descriptive characteristics and provisional pravalce rates. Poster session presentation at the annual meeting of the Society for Behavioral Medicine, New Orleans, LA.

Länsstyrelsen. (2015). Osynlig synlig verklighet - Prostitution i Jönköpings län. Jönköping, Sweden: Länsstyrelsen Jönköping. 
Maniglio, R. (2011). The role of child sexual abuse in the etiology of suicide and non-suicidal selfinjury. Acta Psychiatrica Scandinavica, 124(1), 30-41. doi:10.1111/j.1600-0447.2010.01612.x

Markham, A. N. (2011). Internet Research. In D. Silverman (Ed.), Qualitative reearch (Vol. 3, pp. 111-127). London: SAGE Publications.

McElvaney, R., Greene, S., \& Hogan, D. (2014). To Tell or Not to Tell? Factors Influencing Young People's Informal Disclosures of Child Sexual Abuse. Journal of Interpersonal Violence, 29(5), 928-947. doi:10.1177/0886260513506281

McNeal, B. A., \& Walker, J. T. (2016). Parental Effects on the Exchange of Sex for Drugs or Money in Adolescents. American Journal of Criminal Justice, 41(4), 710-731. doi:10.1007/s12103015-9313-7

Messman-Moore, T. L., \& Long, P. J. (2003). The role of childhood sexual abuse sequelae in the sexual revictimization of women: An empirical review and theoretical reformulation. Clinical Psychology Review, 23(4), 537-571. doi:10.1016/S0272-7358(02)00203-9

Messman-Moore, T. L., Walsh, K. L., \& DiLillo, D. (2010). Emotion dysregulation and risky sexual behavior in revictimization. Child Abuse \& Neglect, 34(12), 967-976. doi:10.1016/j.chiabu.2010.06.004

Miller-Perrin, C., \& Wurtele, S. K. (2017). Sex Trafficking and the Commercial Sexual Exploitation of Children. Women and Therapy, 40(1-2), 123-151. doi:10.1080/02703149.2016.1210963

Miron, L. R., \& Orcutt, H. K. (2014). Pathways from childhood abuse to prospective revictimization: depression, sex to reduce negative affect, and forecasted sexual behavior. Child Abuse \& Neglect, 38(11), 1848-1859. doi:10.1016/j.chiabu.2014.10.004

Mitchell, K., Moynihan, M., Pitcher, C., Francis, A., English, A., \& Saewyc, E. (2017). Rethinking research on sexual exploitation of boys: Methodological challenges and recommendations to optimize future knowledge generation. Child Abuse \& Neglect, 66, 142-151. doi:10.1016/j.chiabu.2017.01.019

Mossige, S., Ainsaar, M., \& Svedin, C. (2007). The baltic sea regional stuyd of adolescents' sexuality. . Oslo, Norway: Norsk institutt for forkning om oppvekst, velferd och aldring.

Moynihan, M., Mitchell, K., Pitcher, C., Havaei, F., Ferguson, M., \& Saewyc, E. (2018). A systematic review of the state of the literature on sexually exploited boys internationally. Child Abuse \& Neglect, 76, 440-451. doi:10.1016/j.chiabu.2017.12.003

Muehlenkamp, J. J. (2005). Self-injurious behavior as a separate clinical syndrome. American Journal of Orthopsychiatry, 75(2), 324-333. doi:10.1037/0002-9432.75.2.324

Muehlenkamp, J. J., Claes, L., Havertape, L., \& Plener, P. L. (2012). International prevalence of adolescent non-suicidal self-injury and deliberate self-harm. Child and Adolescent Psychiatry and Mental Health, 6. doi:10.1186/1753-2000-6-10 
Møhl, B., La Cour, P., \& Skandsen, A. (2014). Non-Suicidal Self-Injury and Indirect Self-Harm Among Danish High School Students. Scandinavian Journal of Child and Adolescent Psychiatry and Psychology, 2(1), 11-18.

Nettelbladt, P., Hansson, L., Stefansson, C. G., Borgquist, L., \& Nordström, G. (1993). Test characteristics of the Hopkins Symptom Check List-25 (HSCL-25) in Sweden, using the Present State Examination (PSE-9) as a caseness criterion. Social Psychiatry and Psychiatric Epidemiology, 28(3), 130-133. doi:10.1007/BF00801743

Niedtfeld, I., Schulze, L., Kirsch, P., Herpertz, S. C., Bohus, M., \& Schmahl, C. (2010). Affect regulation and pain in borderline personality disorder: a possible link to the understanding of self-injury. Biolgical Psychiatry, 68(4), 383-391. doi:10.1016/j.biopsych.2010.04.015

Nilsson, D., Wadsby, M., \& Svedin, C. G. (2008). The psychometric properties of the Trauma Symptom Checklist For Children (TSCC) in a sample of Swedish children. Child Abuse \& Neglect, 32(6), 627-636. doi:10.1016/j.chiabu.2007.09.009

Nock, M. K. (2009). Why do people hurt themselves?: New insights into the nature and functions of self-injury. Current Directions in Psychological Science, 18(2), 78-83. doi:10.1111/j.14678721.2009.01613.x

Nock, M. K. (2010). Self-injury. Annual Review of Clinical Psychology, 6, 339-363. doi:10.1146/annurev.clinpsy.121208.131258

Nock, M. K., Holmberg, E. B., Photos, V. I., \& Michel, B. D. (2007). Self-Injurious Thoughts and Behaviors Interview: Development, Reliability, and Validity in an Adolescent Sample. Psychological Assessment, 19(3), 309-317. doi:10.1037/1040-3590.19.3.309

Nock, M. K., \& Prinstein, M. J. (2004). A functional approach to the assessment of self-mutilative behavior. Journal of Consulting and Clinical Psychology, 72(5), 885-890. doi:10.1037/0022006X.72.5.885

Orcutt, H. K., Cooper, M. L., \& Garcia, M. (2005). Use of sexual intercourse to reduce negative affect as a prospective mediator of sexual revictimization. Journal of Traumatic Stress, 18(6), 729739. doi:10.1002/jts.20081

Osuch, E., Ford, K., Wrath, A., Bartha, R., \& Neufeld, R. (2014). Functional MRI of pain application in youth who engaged in repetitive non-suicidal self-injury vs. psychiatric controls. Psychiatry Research, 223(2), 104-112. doi:10.1016/j.pscychresns.2014.05.003

Patton, M. Q. (2015). Qualitative research \& evaluation methods : integrating theory and practice (4 ed.). Thousand Oaks, California: SAGE Publications,.

Pedersen, W., \& Hegna, K. (2003). Children and adolescents who sell sex: A community study. Social Science and Medicine, 56(1), 135-147. doi:10.1016/S0277-9536(02)00015-1

Penn, J. V., Esposito, C. L., Schaeffer, L. E., Fritz, G. K., \& Spirito, A. (2003). Suicide attempts and self-mutilative behavior in a juvenile correctional facility. Journal of the American Academy of Child and Adolescent Psychiatry, 42(7), 762-769. doi:10.1097/01.CHI.0000046869.56865.46 
Penning, S. L., \& Collings, S. J. (2014). Perpetration, revictimization, and self-injury: Traumatic reenactments of child sexual abuse in a nonclinical sample of south african adolescents. Journal of Child Sexual Abuse, 23(6), 708-726. doi:10.1080/10538712.2014.931319

Plener, P. L., Bubalo, N., Fladung, A. K., Ludolph, A. G., \& Lule, D. (2012). Prone to excitement: adolescent females with Non-suicidal self-injury (NSSI) show altered cortical pattern to emotional and NSS-related material. Psychiatry Research, 203(2-3), 146-152. doi:10.1016/j.pscychresns.2011.12.012

Polisen. (2014). Manniskohandel för sexuella och andra ändamål. Lägesrapport 14.

Polisen. (2016). Männsikohandel för sexualla ändamål lägesrapport 17. Stockholm: Polismyndigheten.

Polisen. (2017). Människohandel för sexualla ändamål Lägesrapport 18. Retrieved from

Priebe, G., Bäckström, M., \& Ainsaar, M. (2010). Vulnerable adolescent participants' experience in surveys on sexuality and sexual abuse: Ethical aspects. Child Abuse \& Neglect, 34(6), 438-447. doi:10.1016/j.chiabu.2009.10.005

Priebe, G., \& Svedin, C. G. (2008). Child sexual abuse is largely hidden from the adult society. An epidemiological study of adolescents' disclosures. Child Abuse \& Neglect, 32(12), 1095-1108. doi:10.1016/j.chiabu.2008.04.001

Rand, A. (2010). It Can't Happen in My Backyard: The Commercial Sexual Exploitation of Girls in the United States. Child \& Youth Services, 31(3-4), 138-156. doi:10.1080/0145935x.2009.524480

Ratner, P. A., Johnson, J. L., Shoveller, J. A., Chan, K., Martindale, S. L., Schilder, A. J., . . Hogg, R. S. (2003). Non-consensual sex experienced by men who have sex with men: Prevalence and association with mental health. Patient Education and Counseling, 49(1), 67-74. doi:10.1016/S0738-3991(02)00055-1

Reitz, S., Kluetsch, R., Niedtfeld, I., Knorz, T., Lis, S., Paret, C., . . Schmahl, C. (2015). Incision and stress regulation in borderline personality disorder: neurobiological mechanisms of selfinjurious behaviour. British Journal of Psychiatry, 207(2), 165-172. doi:10.1192/bjp.bp.114.153379

Roe-Sepowitz, D. E. (2012). Juvenile entry into prostitution: the role of emotional abuse. Violence Against Women, 18(5), 562-579. doi:10.1177/1077801212453140

Rothman, E. F., Bazzi, A. R., \& Bair-Merritt, M. (2015). "Ill do whatever as long as you keep telling me that I'm important": A case study illustrating the link between adolescent dating violence and sex trafficking victimization. Journal of Applied Research on Children, 6(1).

Sahlin, H., Bjureberg, J., Gratz, K. L., Tull, M. T., Hedman, E., Bjärehed, J., . . Hellner, C. (2017). Emotion regulation group therapy for deliberate self-harm: A multi-site evaluation in routine care using an uncontrolled open trial design. BMJ Open, 7(10). doi:10.1136/bmjopen-2017016220 
Sandanger, I., Moum, T., Ingebrigtsen, G., Sørensen, T., Dalgard, O. S., \& Bruusgaard, D. (1999). The meaning and significance of caseness: The Hopkins Symptom Checklist-25 and the Composite International Diagnostic Interview II. Social Psychiatry and Psychiatric Epidemiology, 34(1), 53-59. doi:10.1007/s001270050112

Schauer, M., \& Elbert, T. (2010). Dissociation following traumatic stress etiology and treatment. Journal of Psychology, 218(2), 109-127. doi:10.1027/0044-3409/a000018

Schulze, L., Schmahl, C., \& Niedtfeld, I. (2016). Neural Correlates of Disturbed Emotion Processing in Borderline Personality Disorder: A Multimodal Meta-Analysis. Biological Psychiatry, 79(2), 97-106. doi:10.1016/j.biopsych.2015.03.027

Socialdepartimentet. (1998). Nationell handlingplan mot kommersiell sexual exploatering av barn. Stockholm Socialdepartimentet.

Song, J., \& Morash, M. (2016). Materialistic desires or childhood adversities as explanations for girls' trading sex for benefits. International Journal of Offender Therapy and Comparative Criminology, 60(1), 62-81. doi:10.1177/0306624X14543769

St. Germain, S. A., \& Hooley, J. M. (2012). Direct and indirect forms of non-suicidal self-injury: Evidence for a distinction. Psychiatry Research, 197(1-2), 78-84. doi:10.1016/j.psychres.2011.12.050

Stanley, B., Sher, L., Wilson, S., Ekman, R., Huang, Y. Y., \& Mann, J. J. (2010). Non-suicidal selfinjurious behavior, endogenous opioids and monoamine neurotransmitters. Journal of Affective Disorders, 124(1-2), 134-140. doi:10.1016/j.jad.2009.10.028

Statistics Sweden. (2016). Retrieved from http://www.statistikdatabasen.scb.se

Steel, J. L., \& Herlitz, C. A. (2005). The association between childhood and adolescent sexual abuse and proxies for sexual risk behavior: A random sample of the general population of Sweden. Child Abuse \& Neglect, 29(10), 1141-1153. doi:10.1016/j.chiabu.2004.10.015

Stockholm stad. (2017). Barn och unga som har sex mot ersättning - Sexuell utsatthet och exploatering. Slutrapport 2014-2016. Retrieved from https://insynsverige.se/documentHandler.ashx?did=1893752

Strand, B. H., Dalgard, O. S., Tambs, K., \& Rognerud, M. (2003). Measuring the mental health status of the Norwegian population: A comparison of the instruments SCL-25, SCL-10, SCL-5 and MHI-5 (SF-36). Nordic Journal of Psychiatry, 57(2), 113-118. doi:10.1080/08039480310000932

Svedin, C. G., \& Priebe, G. (2004). Ungdomars sexualitet - attityder och erfarenheter. In Statens offentliga utredningar 2004:71. Stockholm: Regeringskansliet.

Svedin, C. G., \& Priebe, G. (2007). Selling sex in a population-based study of high school seniors in Sweden: Demographic and psychosocial correlates. Archives of Sexual Behavior, 36(1), 21-32. doi:10.1007/s10508-006-9083-x

Svedin, C. G., \& Priebe, G. (2009). Se mig : unga om sex och internet. Stockholm: Ungdomsstyrelsen. 
Svedin, C. G., Priebe, G., Wadsby, M., Jonsson, L. S., \& Fredlund, C. (2015). Unga sex och Internet i en föränderlig värld. Linköping: Linköping University Electronic Press.

Tikkanen, R., Abelsson, J., \& Forsberg, M. (2011). UngKAB09 - kunskap, attityder och sexuella handlingar bland unga (G. Universitet Ed.). Göteborg, Sweden: Institutionen för socialt arbete.

Tull, M. T., Weiss, N. H., Adams, C. E., \& Gratz, K. L. (2012). The contribution of emotion regulation difficulties to risky sexual behavior within a sample of patients in residential substance abuse treatment. Addictive Behaviors, 37(10), 1084-1092. doi:10.1016/j.addbeh.2012.05.001

United Nations. (2000). Protocoal to prevent, suppress and punish trafficking in persons, especially women and children. United Nations.

Van Bruggen, L. K., Runtz, M. G., \& Kadlec, H. (2006). Sexual revictimization: The role of sexual self-esteem and dysfunctional sexual behaviors. Child Maltreatment, 11(2), 131-145. doi: $10.1177 / 1077559505285780$

van de Walle, R., Picavet, C., van Berlo, W., \& Verhoeff, A. (2012). Young Dutch people's experiences of trading sex: a qualitative study. Journal of Sex Research, 49(6), 547-557. doi:10.1080/00224499.2011.618955

Van der Kolk, B. A., \& Fisler, R. E. (1994). Childhood abuse and neglect and loss of self-regulation. Bulletin of the Menninger Clinic, 58(2), 145-168.

van der Kolk, B. A., Roth, S., Pelcovitz, D., Sunday, S., \& Spinazzola, J. (2005). Disorders of extreme stress: The empirical foundation of a complex adaptation to trauma. Journal of Traumatic Stress, 18(5), 389-399. doi:10.1002/jts.20047

Vanwesenbeeck, I. (2013). Prostitution push and pull: Male and female perspectives. Journal of Sex Research, 50(1), 11-16. doi:10.1080/00224499.2012.696285

Weiss, N. H., Sullivan, T. P., \& Tull, M. T. (2015). Explicating the role of emotion dysregulation in risky behaviors: A review and synthesis of the literature with directions for future research and clinical practice. Current Opinion in Psychology, 3, 22-29. doi:10.1016/j.copsyc.2015.01.013

Wilson, H. W., \& Widom, C. S. (2010). The role of youth problem behaviors in the path from child abuse and neglect to prostitution: A prospective examination. Journal of Research on Adolescence, 20(1), 210-236. doi:10.1111/j.1532-7795.2009.00624.x

Wilson, K., Asbridge, M., Kisely, S., \& Langille, D. (2010). Associations of risk of depression with sexual risk taking among adolescents in Nova Scotia high schools. Canadian Journal of Psychiatry, 55(9), 577-585. doi:10.1177/070674371005500906

World Medical Association. (2017). Declaration of Helsinki - Ethical Prinicpals for Medical Research Involving Human Subjects. Retrieved from https://www.wma.net/policies-post/wmadeclaration-of-helsinki-ethical-principles-for-medical-research-involving-human-subjects/ 
Zetterqvist, M. (2015). The DSM-5 diagnosis of nonsuicidal self-injury disorder: A review of the empirical literature. Child and Adolescent Psychiatry and Mental Health, 9(1). doi:10.1186/s13034-015-0062-7

Zetterqvist, M., Lundh, L. G., Dahlstrom, O., \& Svedin, C. G. (2013). Prevalence and function of non-suicidal self-injury (NSSI) in a community sample of adolescents, using suggested DSM-5 criteria for a potential NSSI disorder. Journal of Abnormal Child Psychology, 41(5), 759-773. doi:10.1007/s10802-013-9712-5

Zetterqvist, M., Svedin, C. G., Fredlund, C., Priebe, G., Wadsby, M., \& Jonsson, L. S. (2018). Selfreported nonsuicidal self-injury (NSSI) and sex as self-injury (SASI): Relationship to abuse, risk behaviors, trauma symptoms, self-esteem and attachment. Psychiatry Research, 265, 309316. doi:10.1016/j.psychres.2018.05.013 
Appendix Questionnaire used for Study IV

Detta är en enkät som vänder sig till dig som är över 15 år och har eller har haft erfarenhet av sex som självskada. Med sex som självskada menar vi;

Att du upprepade gånger har sökt dig till sexuella situationer som har gett dig fysisk och/eller psykisk skada och där detta har påverkat dig i ditt liv.

Enkäten är helt anonymt och du kan avbryta när som helst. Allt du skriver kommer avidentifieras så att det inte kan knytas till någon person eller situation.

Det finns ingen begränsning i hur mycket text som kan skrivas. Ordet är ditt!

1. Hur gammal är du?

2. Vad har du för könsidentitet t.ex. tjej, kille icke-binär?

3. Vad brukar du göra för att hantera jobbiga känslor och händelser?

4. Berätta om dina erfarenheter av sex som självskada

4a På vilket sätt har du haft sex som självskada?

4b. Hur började det? 
4c. Hur gammal var du när du hade sex som självskada? Har du det fortfarande?

4d. Vad fick det att fortgå?

4e. Berätta om ett typiskt tillfälle när du hade sex som självskada, hur gick det till?

4f Tänk på ett typiskt tillfälle, om detta skedde med en annan person, vilken relation hade du till den andra personen och vilken ålder och kön hade hen?

4g. Om du har slutat, vad fick dig att sluta?

5. Vad har du för erfarenheter av hjälp och stöd när du hade sex som självskada?

6. Vad hade du velat ha för hjälp, stöd eller bemötande från hälso- och sjukvården eller andra organisationer som jobbar med hjälp och stöd när du hade sex som självskada?

Om du önskar samtalsstöd efter att du svarat på enkäten är du välkommen att kontakta Stockholms Tjejjour via mail, chatt eller stödtelefon. Andra organisationer som jobbar med hjälp och stöd för personer med sex som självskada är 1000 möjligheter, Killfrågor.se och Pegasus (RFSL ungdom). För kontaktuppgifter se informationsbrevet. 


\section{Publications}

The publications associated with this thesis have been removed for copyright reasons. For more details about these see:

http://urn.kb.se/resolve?urn=urn:nbn:se:liu:diva-153569 


\section{FACULTY OF MEDICINE AND HEALTH SCIENCES}

Linköping University Medical Dissertation No. 1645, 2019

Department of Clinical and Experimental Medicine

Linköping University

SE-581 83 Linköping, Sweden

www.liu.se 